\title{
A large and unusually colored new snake species of the genus Tantilla (Squamata; Colubridae) from the Peruvian Andes
}

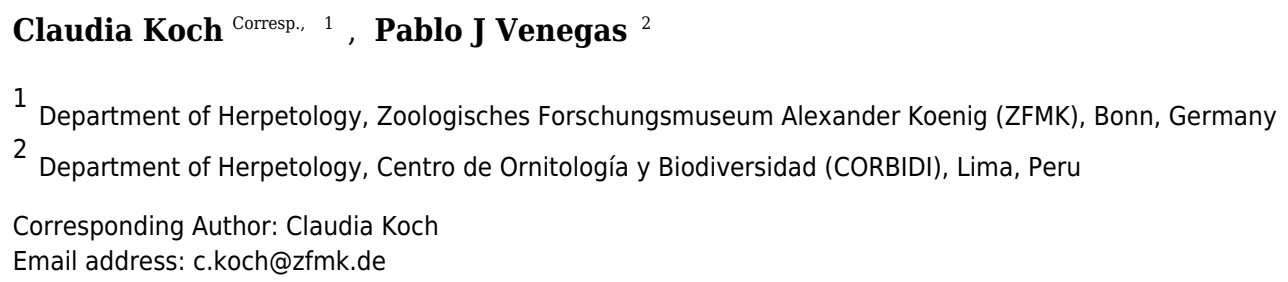

A new colubrid species of the genus Tantilla is described from the dry forest of the Northern Peruvian Andes on the basis of two specimens which exhibit a conspicuous sexual dimorphism. It represents the third species of the genus in Peru. The new species is easily distinguished from its congeners on the basis of mtDNA sequence divergence and by the combination of scalation characteristics and the unusual transversely-banded color pattern on the dorsum. A detailed description of the skull morphology of the new species is given based on micro-computed tomography images. The habitat of this new species is gravely threatened due to human interventions. Thorough investigation and conservation actions in the intern-andean valley Marañón River of is urgently needed. 
1 A large and unusually colored new snake species of the genus Tantilla (Squamata;

2 Colubridae) from the Peruvian Andes

3 Claudia Koch ${ }^{1} \&$ Pablo J. Venegas ${ }^{2}$

4

$5{ }^{1}$ Zoologisches Forschungsmuseum Alexander Koenig (ZFMK), Adenauerallee 160, 53113 Bonn,

6 Germany

$7 \quad{ }^{2}$ Centro de Ornitología y Biodiversidad (CORBIDI), Santa Rita 117, Huertos de San Antonio,

8 Surco, Lima, Perú

9 Corresponding author: Claudia Koch, E-mail: c.koch@zfmk.de 
10 ABSTRACT

11 A new colubrid species of the genus Tantilla from the dry forest of the northern Peruvian Andes

12 is described on the basis of two specimens, which exhibit a conspicuous sexual dimorphism.

13 Tantilla tjiasmantoi sp. nov. represents the third species of the genus in Peru. The new species is

14 easily distinguished from its congeners by the combination of scalation characteristics and the

15 unusual transversely-banded color pattern on the dorsum. A detailed description of the skull

16 morphology of the new species is given based on micro-computed tomography images. The

17 habitat of this new species is gravely threatened due to human interventions. Conservation efforts

18 are urgently needed in the inter-Andean valley of the Marañón River.

Key words: Dry forest, endemic, hemipenes morphology, inter-Andean valley, La Libertad, Marañón, micro-computed tomography, osteology, skull morphology, osteology, phylogenetic relationship, Reptilia, Serpentes, X-ray

\section{INTRODUCTION}

Seasonally dry tropical forests (SDTF) are characterised by a distinct seasonality with several months of arid-like conditions in which many plants lose their leaves (Murphy \& Lugo, 1986). In South America SDTFs are discontinuously distributed and can occupy large areas such as the Caatinga in northeastern Brazil or small fragments as being found in inter-Andean valleys of Peru or Ecuador (Werneck et al., 2011). Nevertheless, the different areas of South American SDTFs are very divers and the species compositions differ substantially (Linares-Palomino, 2006; Miles et al., 2006; DRYFLOR, 2016). However, SDTFs are considered as being one of the most threatened tropical ecosystems with a strong rate of annual deforestation (Janzen, 1988; Miles et al., 2006; Pennington et al., 2006; Linares-Palomino et al., 2011; DRYFLOR, 2016). The Equatorial dry forest is one representative of this forest type, which expands from southern Ecuador to the northern part of Peru (Brack, 1986; Särkinen et al., 2011; Venegas, 2005), where it extends southward in two small stripes. One stripe continues along the coast west of the Andes, whereas the other penetrates the valley of the Marañón River and its tributaries. This North-to- 
40 expands from the Huancabamba Depression in the North along the flanks of the Chinchipe,

41 Chamaya, Huancabamba and Utcubamba rivers and tributaries (Departments of Piura,

42 Cajamarca, Amazonas) southward along the deep and narrow valley of the Marañón River to the

43 Department of La Libertad. Although it has so far rarely been studied with respect to its flora and

44 fauna, recent studies indicate that especially this inter-Andean part of dry forest, is home to a high

45 proportion of endemic species (Statterfield et al., 1998; Bridgewater et al., 2003; Linares-

46 Palomino, 2006; Koch, Venegas \& Böhme, 2006, 2015; Koch et al., 2011, 2013; Venegas et al.,

47 2008; Särkinen et al., 2011). According to Linares-Palomino (2006) this region is home to 184

48 woody plant species, including 69 Peruvian endemics. Characteristic representatives of this xeric

49 vegetation are drought-resistant trees (e.g. Acacia, Ceiba, Cordia, Eriotheca, Hura, Prosopis),

50 cacti plants (e.g. Armatocereus, Browningia, Espostoa), dense shrubs (e.g. Mimosa, Croton) and

51 ground vegetation layer (e.g. Opuntia, Poaceae). Unfortunately, this region is facing multiple and

52 complex threats due to logging, agriculture and narcotics plantations, mining activities, and above

53 all due to several planned hydroelectric projects that will lead to flooding of vast portions of the

54 inter-Andean dry forest (Q \& V Ingenieros SAC, 2007; Finer \& Jenkins, 2012; Lees et al., 2016).

55 These threats, together with the enormous lack of knowledge that still exists about its

56 biodiversity, and the fact that no protected area has so far been designated in the inter-Andean

57 part of the Equatorial dry forest (IUCN \& UNEP-WCMC, 2016), highlights the urgent priority

58 for conservation and research activities in this area.

59 To contribute to the knowledge of the peculiar herpetofauna of the Andean dry forest, we

60 conducted fieldwork in inter-Andean valleys of the northern Peruvian Departments of Amazonas,

61 Cajamarca, and La Libertad and surveyed 28 localities along a stretch of more than $350 \mathrm{~km}$ of the

62 Marañón River and its tributaries. In two of the southernmost investigation areas in the

63 Department of La Libertad, we collected each a specimen of a colubrid species, which was

64 difficult to assign to any of the known genera based on traits of external morphology alone.

65 However, a phylogenetic analysis based on 12S and 16S rRNA together with a comparison of the

66 skull morphology via micro-computed tomography (micro-CT) scans revealed sufficient

67 evidence to place it in the genus Tantilla Baird \& Girard, 1853.

68 Currently, 61 species within the genus Tantilla are recognized (Wilson \& Mata-Silva, 2015;

69 Mata-Silva \& Wilson, 2016). Twelve species occur in mainland South America, of which only

70 two are found in Peru: T. capistrata Cope, 1875 and T. melanocephala (Linnaeus, 1758). Most

71 species of the genus have either a uniformly colored or a longitudinally striped dorsal color 
72 pattern. Only T. shawi Taylor, 1949 from Mexico, T. semicincta (Duméril, Bibron \& Duméril,

73 1854) from Colombia and Venezuela, and T. supracincta (Peters, 1863) from Colombia, Costa

74 Rica, Ecuador, Nicaragua, and Panama have a transversely-banded color pattern on the dorsal

75 part of the body (Wilson, 1976; Wilson \& Mata-Silva, 2015).

76 Reviewing published information on morphological characteristics of all other species of the

77 genus Tantilla (Wilson, 1987; 1999; Sawaya \& Sazima, 2003; Townsend et al., 2013; Wilson \&

78 Mata-Silva, 2014; 2015) revealed that the collected specimens can be easily differentiated from

79 others of the genus by its comparatively high number of ventral scales and other scalation

80 characteristics, its relatively large size, and transversely-banded color pattern. Herein a detailed

81 description of the new species is given.

\section{MATERIALS AND METHODS}

Fieldwork, data sampling and Zoobank registration

85 The new species was detected during visual encounter surveys (Crump \& Scott, 1994) during our fieldwork conducted between March 2009 and November 2010. Altitudes above sea level and geographic coordinates were recorded with a GPS (Garmin GPSMap 60CSx) using the geodetic datum WGS84. Air temperatures and humidity were taken with a digital thermo-hygrometer (Extech) using an external sensor. All the necessary research and collecting (0020-2009-AGDGFFS-DGEFFS, 0424-2010-AG-DGFFS-DGEFFS) and export permits (003983-AG-DGFFS) for this study were issued by the Ministerio de Agricultura of the government of Peru (Ministerio de Agricultura). Both specimens were collected by hand, photographed in live and subsequently euthanized with the narcotic $\mathrm{T} 61^{\circledR}$. Tissue samples were extracted from the muscle of the lateral body and stored in 96\% ethanol. Specimens were placed in 10\% formalin for fixation for about 12 hours, and ultimately stored in 70\% ethanol. Finally the holotype (CORBIDI 7726) was deposited in the herpetological collection of the Centro de Ornitología y Biodiversidad, Lima, Peru (CORBIDI) and the paratype (ZFMK 95238) was deposited in the collection of the Zoologisches Forschungsmuseum Alexander Koenig, Bonn, Germany (ZFMK). The electronic version of this article in Portable Document Format (PDF) will represent a published work according to the International Commission on Zoological Nomenclature (ICZN), and hence the 
102 electronic edition alone. This published work and the nomenclatural acts it contains have been

103 registered in ZooBank, the online registration system for the ICZN. The ZooBank LSIDs (Life

104 Science Identifiers) can be resolved and the associated information viewed through any standard

105 web browser by appending the LSID to the prefix http://zoobank.org/. The LSIDs for this

106 publication is: urn:lsid:zoobank.org:pub:00EBF842-3AFA-4913-B381-95BDF86DAFAB. The

107 online version of this work is archived and available from the following digital repositories:

108 PeerJ, PubMed Central and CLOCKSS.

109 Data on morphological traits of other South American colubrid species and genera were taken

110 from Peracca (1904), Van Denburgh (1912), Werner (1924), Stuart \& Bailey (1941), Slevin

111 (1942), Smith \& Taylor (1945), Stuart (1949; 1954), Peters (1960), Fritts \& Smith (1969), Peters,

112 Donoso-Barros \& Orejas-Miranda (1970), Villa (1971; 1990), Myers (1973), Wilson (1976;

113 1987; 1999), Wilson \& Mena (1980), Savages \& Donnelly (1988), Perez-Santos \& Moreno

114 (1988), Savage \& Crother (1989), McCranie \& Wilson (1991a; 1991b; 1992), McCranie \& Villa

115 (1993), Cei (1993), Ferrarrezzi (1993), Puorto \& Ferrarrezzi (1993), Myers \& Cadle (1994),

116 Smith \& Campbell (1994), Campbell, Camarillo \& Ustach (1995), Zaher (1996; 1999), Franco,

117 Marques \& Puorto (1997), Campbell (1998), Campbell \& Smith (1998), Starace (1998),

118 Kornacker (1999), Savage (2002), Sawaya \& Sazima (2003), Köhler (2003; 2008), McCranie \&

119 Castaneda (2004), Solórzano (2004), Stafford (2004), Lema, D’Agostini \& Cappelari (2005),

120 Scott et al. (2006), Cacciali, Carreira \& Scott (2007), Harvey et al. (2008), Jansen \& Köhler

121 (2008), Zaher et al. (2009), Myers (2011), Passos, Ramos \& Pereira (2012), Moura, Caldeira

122 Costa \& Magalhães Pirani (2013), Townsend et al. (2013) Myers \& McDowell (2014), Wilson \& 123 Mata-Silva $(2015 ; 2014)$.

Morphological analyses

126 Measurements of head and scales were taken with a digital caliper and rounded to the nearest 0.1

$127 \mathrm{~mm}$, snout-vent length and tail length were taken with a measuring tape and rounded to the

128 nearest $1 \mathrm{~mm}$. Morphometric and meristic characters are abbreviated as follows: SVL (snout-

129 vent length, from tip of snout to cloaca); TL (tail length); HW (head width across supraoculars);

$130 \mathrm{HH}$ (head height at highest part of head); HL (head length); DSN (distance from tip of snout to

131 nostril); DNE (distance from nostril to anterior margin of eye); ED (eye diameter); MBD (body

132 diameter at midbody); MTD (midtail diameter). The number of ventral scales was counted in

133 longitudinal row from mental to anal plate, and the number of subcaudal scales was counted in 
134 longitudinal row from the cloaca to the tip of the tail (Dowling, 1951). The number of dorsal

135 scales rows around the body was counted at three different points: (1) at a head's length behind

136 the head; (2) at midbody; (3) at a head's length before the cloaca. A dissecting microscope was

137 used to count and characterize small scales and to identify the number of teeth in the male

138 paratype.

139 For obtaining information on skeletal morphology, specimens were X-rayed in 2D (Faxitron X140 ray LX60) and in 3D by use of a micro-CT scanner (Bruker Skyscan 1272). Terminology for the 141 skull structures was adopted from Bulloch \& Tanner (1966) and Cundall \& Irish (2008). The 142 structures of the skull are abbreviated as follows: PMX (Premaxilla); NA (nasal); SMX

143 (septomaxilla); F (frontal); PFR (prefrontal); P (parietal); PO (postorbital); PRO (prootic); ST 144 (supratemporal); SO (supraoccipital); EXO (exoccipital); Q (quadrate); MX (maxilla); ECP 145 (ectopterygoid); PAL (palatine); MP (maxillary process of palatine); CHP (chanal process of 146 palatine); PT (pterygoid); BS (basisphenoid); BO (basioccipital).

147 The partially everted hemipenes of the male paratype were removed from the specimen and 148 prepared following Zaher \& Prudente (2003). Finally the organs were scanned with the micro-CT 149 scanner. Left hemipenis was scanned dry, whereas right hemipenis was scanned in alcohol.

150 Terminology for hemipenes morphology follows Zaher (1999).

Phylogenetic analysis

153 Genomic DNA was extracted from the collected tissue samples at the Center for Molecular

154 Biodiversity Research of the ZFMK, using the DNeasy Blood \& Tissue Kit (Qiagen) following 155 the standardized extraction protocol provided by the manufacturer. Two mitochondrial markers, 156 12S rRNA and 16S rRNA, and the nuclear gene RAG1 (recombination-activating gene 1) were 157 amplified using polymerase chain reactions (PCR) having a final volume of $20 \mu \mathrm{l}$ and carried out 158 either on a GeneAmp 2700 or on a Biometra thermal cycler. The QIAGEN® Multiplex PCR Kit 159 (HotStarTaq® DNA Polymerase, Multiplex PCR Buffer with $6 \mathrm{mM} \mathrm{MgCl}$, dNTP Mix, $2 \mu \mathrm{l}$ Q160 solution, $2.3 \mu \mathrm{l}$ ultrapure $\mathrm{H}_{2} \mathrm{O}$ ) was used for the reaction for all three genes with $1.6 \mu \mathrm{l}$ of each 161 primer, and $2.5 \mu \mathrm{l}$ of extracted DNA. To amplify the $12 \mathrm{~S}$ fragment the roughly universal primer 162 pair 12SA-L (light chain) and 12SB-H (heavy chain) of Kocher et al. (1989) was used. The 16S 163 fragment was amplified using the likewise universal primer pair 16sar-L (light chain) and 16sbr- 
$164 \mathrm{H}$ (heavy chain) of Palumbi et al. (1991). For amplification of RAG1 the primer pair RAG1f2

165 (light chain) and RAG1r3 (heavy chain) of Schulte \& Cartwright (2009) were used.

166 Amplification with the $12 \mathrm{~S}$ primer pair started with an initial denaturation step for $90 \mathrm{~s}$ at $94^{\circ} \mathrm{C}$, 167 and 38 cycles were run with denaturing for $45 \mathrm{~s}$ at $94^{\circ} \mathrm{C}$, annealing for $60 \mathrm{~s}$ at $50^{\circ} \mathrm{C}$, elongation

168 for $120 \mathrm{~s}$ at $74^{\circ} \mathrm{C}$, the final elongation for $300 \mathrm{~s}$ at $74^{\circ} \mathrm{C}$, and cooling at $10^{\circ} \mathrm{C}$. Amplification with 169 the $16 \mathrm{~S}$ primer pair started with an initial denaturation step for $900 \mathrm{~s}$ at $95^{\circ} \mathrm{C}$, followed by 15 170 cycles of denaturation for $35 \mathrm{~s}$ at $94^{\circ} \mathrm{C}$, annealing for $90 \mathrm{~s}$ at $60^{\circ} \mathrm{C}$, elongation for $90 \mathrm{~s}$ at $72^{\circ} \mathrm{C}$, 171 plus 25 cycles of denaturation for $35 \mathrm{~s}$ at $94^{\circ} \mathrm{C}$, annealing for $90 \mathrm{~s}$ at $45^{\circ} \mathrm{C}$, elongation for $90 \mathrm{~s}$ at $17272^{\circ} \mathrm{C}$, the final elongation for $600 \mathrm{~s}$ at $72^{\circ} \mathrm{C}$, and cooling at $10^{\circ} \mathrm{C}$. Amplification with the RAG1 173 primer pair started with an initial denaturation step for $900 \mathrm{~s}$ at $95^{\circ} \mathrm{C}$, and 40 cycles were run with 174 denaturing for $20 \mathrm{~s}$ at $94^{\circ} \mathrm{C}$, annealing for $50 \mathrm{~s}$ at $60^{\circ} \mathrm{C}$, elongation for $90 \mathrm{~s}$ at $72^{\circ} \mathrm{C}$, the final 175 elongation for $600 \mathrm{~s}$ at $72^{\circ} \mathrm{C}$, and cooling at $10^{\circ} \mathrm{C}$. After the PCR, each sample proving successful 176 DNA amplification in an agarose gel electrophoresis, was purified for sequencing using the 177 QIAquick PCR Purification Kit (Qiagen). Subsequently, the samples were sequenced by

178 Macrogen Europe Laboratory (Amsterdam, Netherlands). Obtained sequences were checked with 179 the original chromatograph data using BioEdit 7.5.2 (Hall, 1999). The 12S rRNA and 16S rRNA 180 data was supplemented with sequences of 48 species representing 27 genera of American 181 colubrid snakes obtained from GenBank. Accession numbers are provided in Table 1. Sequence 182 alignment was done with MAFFT (Katoh, Asimenos \& Toh, 2009) and manually corrected where 183 necessary. Ambiguous sites (namely in the hypervariable regions of the $16 \mathrm{~S}$ rRNA) were 184 identified with Gblocks (Castresana, 2000) and excluded from the alignment during subsequent 185 analyses, resulting in $350 \mathrm{bp}$ and $438 \mathrm{bp}$ for $12 \mathrm{~S}$ and $16 \mathrm{~S}$, respectively. For each gene, GTR $+\mathrm{I}+\mathrm{G}$ 186 was chosen as model of nucleotide substitution by the Akaike information criterion using 187 Modeltest (Posada \& Crandall, 1998) as implemented in the package 'phangorn' for Cran R.

188 Phylogenetic trees were inferred using MrBayes 3.2.6 (Ronquist et al., 2012), estimating model 189 parameters separately for each gene by partitioning the data set. We used a random starting tree 190 and four independent runs with a maximum of 10 million generations each, sampled every 1000.

191 Runs were stopped when the average standard deviation of split frequencies had reached 0.01.

192 Convergence of the Markov chains and effective sample sizes were checked with Tracer v1.6

193 (Rambaut et al., 2014) and the initial 25\% of each run were discarded prior to building a

194 consensus tree. In addition to the Bayesian inference (BI), phylogenies were also calculated with

195 Maximum Likelihood (ML) via the RAxML BlackBox (Stamatakis, Hoover \& Rougemont, 196 2008) using the partitioned data, the Gamma model of rate heterogeneity, and 100 bootstraps. 
198 RESULTS

199 Morphological analyses

200 As typical for the genus Tantilla, the two specimens possess a number of 15 smooth dorsal scale 201 rows throughout the body, one preocular, no loreal, no suboculars, $1+1$ temporals, a divided 202 cloacal shield, paired subcaudals (Table 2). Additionally, the skull of the new species is composed 203 of similar bones and bone structures as other species of the genus Tantilla. A comparison with 204 three other congeners (T. capistrata, T. melanocephala and T. relicta) reveals great similarity to 205 our new species with only minor differences in the shape or size of some bones (Fig. 6). Scalation 206 characteristics and dorsal color pattern are very similar in both specimens. Nevertheless, they 207 show conspicuous differences in body size and ventral coloration which are most likely due to 208 sexual dimorphism and/or age difference.

\section{Phylogenetic analysis}

211 Fragments of the mitochondrial gene 16S (526 bps) and nuclear gene RAG1 (1050 bps) of both 212 specimens were compared. 16S showed no differences between specimens, and RAG1 revealed 213 only a single base pair variation. The strong genetic similarity coupled with the weak 214 morphological variation suggests these specimens are the same species.

215 The Bayesian consensus tree (Fig. 1) obtained from 788 bp of mitochondrial DNA (12S and 16S 216 rRNA) was based on 3600 sampled trees and effective sample sizes were $>1000$, which indicated 217 good mixing of the Markov chains. Although the topologies obtained from BI and ML (Fig. S1) 218 differ and the nodes were generally not very well resolved in terms of posterior probabilities and 219 bootstrap values, the four species of Tantilla formed a well-supported clade including our two 220 specimens (CORBIDI 7726 and ZFMK 95238). However, node support is lacking between the

221 different species of Tantilla, obscuring the exact relationship between these taxa. 
225 Holotype. CORBIDI 7726 from Pías, Province Pataz, Department of La Libertad, Peru (S 226 0753'56.6', W 77³4'43.8', 1726 m a.s.1), collected by E. Hoyos Granda, A. Beraún and C. 227 Koch on 15 January 2010.

228 Paratype. ZFMK 95238, from Santa Rosa/El Tingo (Marcamachay), Province Cajabamba, 229 Department of La Libertad, Peru (07²1'59.3'” S, 7753'53.0', W, 1154 m a.s.1.), collected by M. 230 Palacios Panta and C. Koch on 13 October 2010.

231 Diagnosis and definition. This comparatively large Tantilla is distinguished from its congeners 232 by the following combination of characters: (1) maximum known SVL of $513 \mathrm{~mm}$ and total 233 length of $638 \mathrm{~mm}$; (2) 179-182 ventrals; (3) 57-65 paired subcaudals; (4) 7 supralabials; (5) eyes 234 small, not visible from below, with round pupils; (6) dorsals smooth, without keels or apical pits, 235 rhomboid, in 15 rows throughout the body; (7) loreals absent; (8) suboculars absent; (9) 2 236 postoculars; (10) $1+1$ temporals; (11) cloacal plate divided; (12) hypapophyses absent on 237 posterior vertebrae; (13) hemipenes single; (14) body with dark bands that are not closed on 238 ventral side; (15) conspicuous sexual dimorphism present.

239 With a maximum known total length of $638 \mathrm{~mm}$ Tantilla tjiasmantoi $\mathrm{sp}$. nov. is among the largest 240 species in the genus, only T. shawi, T. impensa, and T. semicincta reach similar or even larger 241 total length. It can further be easily distinguished from all congeners except for T. shawi, T. 242 semicincta, and T. supracincta by having a transversely-banded color pattern on the dorsal part of 243 the body. The higher number of subcaudals (57-65) differentiates the new species from T. shawi 244 (48-50) and the higher number of ventrals (179-182) further distinguishes it from T. impensa 245 (162-172), T. semicincta (161-176) and T. supracincta (138-151), as well as from the Peruvian 246 species T. capistrata (130-156) and T. melancocephala (125-177). From the other species 247 occurring in mainland South America, it can further be distinguished by a higher number of 248 ventrals as compared to T. alticola (128-145), T. andinista (157), T. boipiranga (156-167), T. 249 miyatai (165-172), T. nigra (137), T. petersi (172), T. insulamontana (144-157), T. reticulata $250(158-173)$.

251 Description of holotype. an adult female with a SVL of $513 \mathrm{~mm}$; TL $125 \mathrm{~mm}$; HL $16.3 \mathrm{~mm}$; HW 25212.2 mm; HH 6.1 mm; TL/Total Length 0.2; SVL/HL 31.5; SVL/HW 42.1; SVL/HH 84.1; 253 HW/HL 0.75; HH/HL 2.7; ED 1.5 mm; HL/ED 10.9; HW/ED 8.1; MBD 11.5 mm; SVL/MBD 254 44.6; DSN 1.5 mm; DNE 3 mm; MTD 2.9 mm. 
255 Body robust, tail long, body and tail round in cross-section; dorsal scales in 15-15-15-rows, 256 without reduction, rhomboid, smooth, lacking keels or apical pits; 182 ventrals; tail distinctly 257 smaller in diameter than the body, long and tapering, tail spine pointed; 57 paired subcaudals; 258 cloacal plate divided.

259 Head (Fig. 2) distinct from the body and depressed, laterally broadened behind the eyes. Rostral 260 visible in dorsal view, slightly triangular with dorsal termination subacute, about 1.9 times wider 261 than high. Snout rounded in dorsal view. Two internasals, subequal, about twice as broad as long, 262 laterally in contact with anterior and posterior nasals. Prefrontals large, 1.2 times broader than 263 long, laterally contacting postnasal, second supralabial and preocular. Frontal slightly hexagonal 264 with dorsal termination acute, about 1.2 times longer than wide, laterally in contact with 265 supraoculars, laterodorsally in contact with parietals. Supraoculars about 2.1 times wider than 266 high. Parietals large, 1.6 times longer than wide, median suture about as long as frontal length. 267 Nostrils located in posterior portion of anterior nasals. Anterior nasals about as high as broad, 268 contacting rostral, internasal, postnasal, and first supralabial. Posterior nasals about 1.8 times 269 longer than high, contacting anterior nasal, internasal, prefrontal, and first and second supralabial. 270 No loreal. Eyes small with round pupils, partly visible in dorsal view, surrounded by one 271 preocular, one supraocular, two postoculars, and third and fourth supralabial. No suboculars.

272 Preoculars almost squarish. Superior postoculars, about 1.5 times longer than high; lower 273 postoculars slightly pentagonal to almost circular. Supralabials $7 / 7$, increasing in size posteriard,

274 last one very large, about 3 times higher and 2.2 times broader than first supralabial, second 275 contacting postnasal and preocular, third contacting prefrontal and eye, fourth contacting eye and 276 lower postocular, fifth contacting lower postocular and anterior temporal, sixth contacting 277 anterior temporal, seventh contacting anterior and posterior temporals, and first scale of 278 dorsolateral and lateral body scale row, respectively. $1+1$ temporals, almost rectangular, 279 separating supralabials 5-7 from parietals, anterior temporal about 2.5 times longer than high on 280 both sides, 1.3 times longer than posterior one on left side and almost twice as long as posterior 281 one on right side of head, posterior temporal 1.8 times longer than high on left side and about 1.1 282 times longer than high on right side of head. Mental subrhombical, 1.4 times broader than long, 283 separated from chinshields by first pair of infralabials, which contact each other along the ventral 284 midline. Infralabials 7/7, fourth largest, second smallest, first to fourth contacting anterior pair of 285 chinshields; fourth infralabial contacting posterior chinshield and first gular scale. Two pairs of 286 almost rectangular chinshields; anterior chinshields about 1.7 times longer than wide and 1.3 
287 times longer than posterior chinshields; posterior chinshields about 2.2 times longer than wide,

288 laterally contacting fourth infralabial, dorsally separated from the ventrals by four gular scales.

289 Trunk vertebrae 185; hypapophyses present on anterior 1/5 of trunk vertebrae, absent on posterior

290 vertebrae; caudal vertebrae 56 (Fig. 4).

291 Coloration. In live, the dorsal ground color of head, body and tail is orange-yellowish, slightly

292 paler laterally, most scales on body and tail with reddish-brown outlines; there are about 27

293 blackish dorsal crossbars on the body that are four to seven scales in length and are stretched

294 across all dorsal scale rows except the most lateral row, slightly longer than ground color

295 interspaces, fused in some parts of the body to form a zigzag band, slightly mottled in some parts

296 with yellow. There are 12 dark tail blotches, reaching to subcaudals on both sides, fused in

297 median part of the tail along the midline to form a zigzag band. Head with a large dark dorsal t-

298 shirt-shaped blotch covering frontal, supraoculars, most of parietals except for the most posterior

299 parts, and posterior part of prefrontals, the dark blotch is laterally extended at eye level, covering

300 orbit, preocular, third supralabial, and adjacent parts of second and fourth supralabials,

301 respectively. Infralabials, rostral and mental yellowish, except for blackish region surrounding the

302 lingual groove. The ventral scales of head and body and subcaudal scales are cream-colored with

303 dark dotted outlines in some parts. The coloration of the tongue is black to grayish-black (Fig. 3).

304 In preservative, the dorsal pattern on body and tail of a light ground color with dark crossbands

305 remains unchanged, likewise the dark coloration of the head; the orange-yellowish dorsal ground

306 color changed to cream and the darker outlines of most dorsal scales disappeared; the ventral

307 coloration changed to grayish-white in some parts (Fig. 3). The coloration of the tongue changed

308 to gray.

309 Variation. The single paratype is a small male with a conspicuous sexual dimorphism in body

310 size and ventral coloration compared to the holotype. As the hemipenes ornamentation is as

311 detailed as in other adult specimens of the genus Tantilla we assumed it to be already sexually

312 mature. Intraspecific variation in scale counts and measurements is shown in Table 2. The

313 paratype further differs from the holotype in the following characters: SVL/HL 24.4; HW/HL

314 0.58; ED 1.1 mm; HL/ED 7.4; HW/ED 4.3; MBD 3.5 mm; SVL/MBD 56.6; DSN 1.0 mm; DNE

$3151.3 \mathrm{~mm}$; MTD $1.3 \mathrm{~mm}$. On the right side this specimen has only 6 infralabials, of which the third

316 one is the largest. 
317 The dorsal ground coloration of the paratype (Fig. 3) in live is bright yellow and there are 35

318 blackish dorsal crossbars on the body and 16 dark tail blotches, some of the latter are fused to

319 form a zigzag band, the black parts are usually not mottled with yellow. The t-shirt-shaped dark

320 pattern on the dorsal surface of the head is also present in this specimen, but there is a dark

321 vertical line on the left side of the head covering whole sixth and adjacent parts of seventh

322 supralabial. On left side of the head posterior part of second infralabial and infralabials three to

323 five are dark, on right side of head the posterior part of third infralabial and the infralabials four

324 to six are dark. The ventral coloration differs from the holotype as the dark dorsal coloration of

325 the paratype continues on the ventral scales, and thus sometimes forming complete rings around

326 the body or creating a checkerboard pattern on the ventral surface of black and cream squares.

327 Cranial osteology. The snout is terminated by a small, single, toothless, median premaxilla. The

328 triangular-shaped dorsal process of the premaxilla is not contacting the anterior portion of the two

329 nasals. The paired nasals are slightly convex and oval-shaped in dorsal view, medially in contact

330 and separate anteriorly to from an interspace. Their posterior edges are in contact with the

331 anterior inner edges of the frontals. The paired frontals are dorsally flat, subrectangular, longer

332 than broad, slightly larger than the nasals, and in close medial contact. The posterolateral edge of

333 each frontal forms a supraorbital ridge which is perforated with two supraorbital foramina. The

334 lateral surface of the frontal forms a major portion of the mesial wall of the orbit. The prefrontal

335 is loosely attached to the anterolateral edge of the frontal. In lateral view, the prefrontal is

336 anteriorly contacting the posterior edge of the nasal and the septomaxilla, and the ventral border

337 is contacting the dorsal surface of the maxilla. The frontals articulate posteriorly with the fused

338 parietals. In dorsal view, the parietal is flat, oval-shaped except for the more or less straight

339 anterior border along the suture with the frontals. It is the largest of the cranial elements and like

340 the frontals, extends laterally far down, reaching ventrally to the basisphenoid. The parietal forms

341 the posterior portion of each orbit. Its posterolateral borders suture with the prootics and its

342 posterior border sutures with the supraoccipital. The postorbitals are narrow, elongate, flattened,

343 slightly curved bones, larger than the prefrontals. They articulate with the anterolateral surface of

344 the parietal and form the dorsoposterior boundary of each orbit. The single supraoccipital is flat,

345 subpentagonal, and broader than long. Laterally it unites with the prootics and posteriorly with

346 the exoccipitals. The paired prootics are largely separated by the broad supraoccipital. Each

347 prootic is subtrapezoidal in dorsal view and is posteriorly bordered by the exoccipital. Laterally it

348 extends far down, reaching ventrally the basisphenoid and the basioccipital. Each prootic has two 
349 large foramen of which the anterior one is anteriorly not enclosed by bone. The posterior foramen 350 is larger than the anterior one. Other smaller foramina pierce each prootic. Posterodorsally each

351 prootic is fused with the elongate, spine-like supratemporal, which connects the posterolateral

352 dorsal part of the skull with the proximal end of the quadrate. Both supratemprals are almost

353 parallel to each other, converging only slightly posteriard. The exoccipitals are dorsally flat, form

354 the posterolateral walls of the braincase and are joined together by a mid-dorsal suture. Ventrally

355 they are resting upon the basioccipital. The basioccipital is pentagonal-shaped and joined

356 anteroventrally with the basisphenoid along a straight transverse suture. The basisphenoid is

357 applied anteriorly without a suture to the narrow, elongate parasphenoid, forming a single bone,

358 which extends anteriorly into the rostrum area and becomes the floor of the orbit. Each maxilla is

359 a curved bar with a small horizontal dorsoposteriorly-pointing process, about midway on the

360 mesial border, that articulates with the ventral surface of the prefrontal. Anterodorsally articulates

361 with the posteroventral surface of the septomaxilla. The posterior end of the maxilla is broadened

362 and received by the flattened, pincers-shaped ectopterygoid, which connects it to the pterygoid.

363 Each maxilla bears sockets for about 18 prediastemal, slightly recurved teeth, followed by two

364 slightly enlarged, ungrooved fangs. The ectopterygoid do not bear teeth. The narrow palatine

365 bears 13 or 14 teeth. The posterior end of each palatine articulates with the anterior end of the

366 pterygoid. At about the height of the third and fourth tooth each palatine possesses a broad,

367 horizontally flattened, lateral maxillary process. At about the height of the sixth to eighth tooth

368 each palatine possesses a similar but median choanal process with the apex directed anteriorly.

369 The pterygoid is a slightly curved, flattened bar with about 17 teeth along the medial border. The

370 subtriangular quadrate articulates with the lateral border of the supratemporal and its distal

371 surface articulates with the mandibular condyle. The mandible is composed of two jaw bones.

372 The anterolateral portion of the jaw is formed by the dentary, which contains a row of about 22 ,

373 slightly recurved teeth. The longer proximal part of each jaw is without teeth. (Fig. 5). There are

374179 trunk vertebrae and 70 caudal vertebrae (Fig. 4).

375 Hemipenial morphology. The hemipenes are unilobed, unicalyculate and noncapitate with a

376 single sulcus spermaticus. The apical part is mostly uniformly spinulate. The hemipenial body is

377 more or less uniformly ornamented with long and thin spines, which increase in size towards the

378 base (Fig. 7).

379 Etymology. The species is dedicated to Wewin Tjiasmanto (Indonesia) in recognition of his

380 support of nature conservation and taxonomic research through the BIOPAT initiative. 
381 Distribution and natural history. This species is so far known from the southern portion of the

382 seasonally dry forest along the Marañón River and its tributaries, from near Santa Rosa de

383 Marcamachay at the Río Crisnejas, Province Cajabamba, and from near Laguna de Pías, Province

384 Pataz, both Department of La Libertad, at elevations of $1154 \mathrm{~m}$ and $1726 \mathrm{~m}$ a.s.1, respectively

385 (Fig. 8 \& 9). The female CORBIDI 7726 was detected on $7^{\text {th }}$ of January 2010 at 12.30 pm resting

386 on a stone. The male ZFMK 95238 was detected on $12^{\text {th }}$ of October 2010 at 8.15 pm on pebbly-

387 clayey ground. Air temperature when animals were sighted was $33.3^{\circ} \mathrm{C}$ and $28.1^{\circ} \mathrm{C}$, respectively.

388

389 DISCUSSION

390 Despite the comparatively close localities ( $>70 \mathrm{~km}$ air distance) and similarities in scale counts

391 and arrangement of scales, the conspicuous differences of both specimens in body size and

392 ventral coloration created some doubt if they represent the same species. A pairwise analysis of

$3931576 \mathrm{bp}$ derived from the mitochondrial gene 16S and the nuclear gene RAG1 showed only a

394 single difference in one base position in the RAG1 fragment, thus strongly supporting the

395 assumption that both specimens belong to the same species. The collection and examination of

396 further specimens is needed to determine whether the differences in size and color pattern are a

397 product of sexual dimorphism or are referred to a different cause (e.g. age dependence,

398 geographic variation).

399 In order to get a general idea of the phylogenetic position of the new species described herein, we 400 performed phylogenetic analyses based on 12S rRNA and 16S rRNA. We did not attempt to 401 conduct a taxonomically extensive analysis of South American Colubridae, instead we preferred

402 to include only those species, for which the two gene regions sequenced in this study were 403 available in GenBank. Our phylogenetic tree based on mitochondrial DNA (Fig. 1) corroborates

404 the assignment of our new species into the genus Tantilla. Both the monophyly of the sampled

405 Tantilla and the conspecificity of our two dimorphic specimens are well supported by the

406 analyses. However, intrageneric relationships remain dubious due to the few species with genetic

407 data available. Moreover, scutellation characteristics and the comparison of the skull morphology

408 via micro-CT scans (Fig. 6) strongly support this hypothesis.

409 With currently 62 species assigned to this genus it represents the second largest genus of New

410 World colubrid snakes, after the genus Atractus. However, taxonomic approaches are limited by

411 the fact that pretty much nothing concrete is known about the phylogenetic relationships within 
412 the genus Tantilla, and its monophyly has not yet been tested adequately. Only few specimens

413 representing fewer than ten species of Tantilla have been included in previous DNA-based

414 studies (e.g. Vidal et al., 2000; Lawson et al., 2005; Burbrink \& Myers, 2015; Schrey et al., 2015;

415 Chambers \& Hebert, 2016). Thus, Tantilla could benefit from a thorough taxonomic treatment

416 involving a stronger genomic sampling component. Such a revision would test species concepts,

417 update their known distributions, reveal their genetic diversity and give some clues about their

418 evolutionary history. Furthermore, with robust molecular data generic designation could be

419 proposed with more confidence.

420 The habitat of this new species is gravely threatened due to human interventions, such as

421 deforestation, mining activities, and intended dam constructions for hydroelectric projects. To

422 date no protected area has been established in the Marañón river valley. We hope that this

423 beautiful and untypically colored new Tantilla could serve as a flagship species, together with

424 several other endemic species of reptiles and birds, for the establishment of conservation

425 strategies in this region. Unless these strategies are implemented the biodiversity found in this

426 unique habitat, including the new, endemic species described here, may fall into serious decline.

\section{ACKNOWLEDGEMENTS}

429 Peter Rühr and Morris Flecks (both ZFMK) kindly helped with the micro-CT imaging and 430 phylogenetic analysis, respectively. We are indebted to Hussam Zaher for sharing his expertise on 431 hemipenes morphology with us. The Ministerio de Agricultura, Peru, kindly provided collecting 432 and export permits. We thank Alfredo Beraún, Erick Hoyos Granda, and Manuel Palacios Panta 433 for assistance during the fieldwork. We are indebted to the residents of Santa Rosa and Laguna de 434 Pías for their hospitality, support and assistance during the fieldwork. 
435 Table 1. Taxa used for phylogenetic analysis and respective GenBank accession 436 numbers.

\begin{tabular}{|c|c|c|c|}
\hline Species & 12S rRNA & 16S rRNA & RAG1 \\
\hline CORBIDI 7726 & KY006875 & KY006877 & KY006874 \\
\hline ZFMK 95238 & & KY006876 & KY006873 \\
\hline Chironius bicarinatus & HM565744 & HM582206 & \\
\hline Chironius carinatus & HM565745 & HM582207 & \\
\hline Chironius exoletus & HM565746 & HM582208 & \\
\hline Chironius flavolineatus & HM565747 & HM582209 & \\
\hline Chironius foveatus & HM565748 & HM582210 & \\
\hline Chironius fuscus & HM565749 & HM582211 & \\
\hline Chironius laevicollis & HM565751 & HM582213 & \\
\hline Chironius monticola & HM565753 & HM582214 & \\
\hline Chironius quadricarinatus & HM565755 & HM582215 & \\
\hline Chironius scurrulus & HM565756 & HM582216 & \\
\hline Clelia bicolor & GQ457787 & GQ457729 & \\
\hline Coluber constrictor & AY122667 & & \\
\hline Coluber flagellum & AY122668 & & \\
\hline Coluber taeniatus & AY122669 & & \\
\hline Dendrophidion percarinatus & HM565757 & HM582217 & \\
\hline Drymarchon corais & HM565758 & HM582218 & \\
\hline Drymobius rhombifer & HM565761 & HM582220 & \\
\hline Drymoluber brazili & HM565760 & HM582219 & \\
\hline Drymoluber dichrous & HM565759 & HM582221 & \\
\hline Erythrolamprus aesculapii & GQ457795 & GQ457736 & \\
\hline Gyalopion canum & KR814624 & KR814641 & \\
\hline Lampropeltis getula & AY122821 & & \\
\hline Lampropeltis mexicana & FJ623962 & & \\
\hline Lampropeltis triangulum & FJ623963 & & \\
\hline Leptodrymus pulcherrimus & KR814627 & KR814649 & \\
\hline Leptophis ahaetulla & HM565762 & HM582222 & \\
\hline Liophis elegantissimus & GQ457808 & GQ457748 & \\
\hline Liophis jaegeri & GQ457809 & GQ457749 & \\
\hline Mastigodryas bifossatus & HM565763 & HM582223 & \\
\hline Mastigodryas boddaerti & HM565764 & HM582224 & \\
\hline Mastigodryas dorsalis & KR814625 & KR814650 & \\
\hline Oxybelis aeneus & HM565765 & HM582225 & \\
\hline Oxybelis wilsoni & KR814626 & KR814647 & \\
\hline Pituophis catenifer & KU833245 & KU833245 & \\
\hline Pituophis lineaticollis & AF512746 & AF512746 & \\
\hline Pseustes poecilonotus & & KR815895 & \\
\hline Rhinobothryum lentiginosum & HM565767 & HM582227 & \\
\hline Salvadora grahamiae & AY122847 & & \\
\hline Scolecophis atrocinctus & KR814619 & KR814642 & \\
\hline Senticolis triaspis & AY122848 & & \\
\hline Spilotes pullatus & HM565768 & HM582228 & \\
\hline Stenorrhina freminvillei & HM565769 & & \\
\hline Symphimus leucostomus & KR814618 & KR814651 & \\
\hline Tantilla armillata & KR814613 & KR814644 & \\
\hline Tantilla impensa & KR814614 & KR814645 & \\
\hline Tantilla melanocephala & AF158424 & AF158491 & \\
\hline
\end{tabular}




\begin{tabular}{lll}
\hline Tantilla vermiformis & KR814615 & KR814646 \\
\hline Xenodon neuwiedi & GQ457841 & GQ457779 \\
\hline
\end{tabular}

437

438 Table 2. Scale counts and measurements of the type specimens of Tantilla tjiasmantoi sp. nov.

\begin{tabular}{|l|l|l|}
\hline & $\begin{array}{l}\text { Holotype } \\
\text { CORBIDI 7726 }\end{array}$ & $\begin{array}{l}\text { O Paratype } \\
\text { ZFMK 95238 }\end{array}$ \\
\hline Dorsal scale rows & $15-15-15$ & $15-15-15$ \\
\hline Ventrals & 182 & 179 \\
\hline Subcaudals & 57 & 65 \\
\hline Supralabials & 7 & 7 \\
\hline Infralabials & 7 & $6-7$ \\
\hline Internasals & 2 & 2 \\
\hline Prefrontals & 2 & 2 \\
\hline Preoculars & 1 & 1 \\
\hline Postoculars & 2 & 2 \\
\hline Supraoculars & 1 & 1 \\
\hline Suboculars & $\mathrm{absent}$ & $\mathrm{absent}$ \\
\hline Loreal & $\mathrm{absent}$ & $\mathrm{absent}$ \\
\hline Anterior temporals & 1 & 1 \\
\hline Posterior temporals & 1 & 1 \\
\hline Sublinguals (paired) & 2 & 2 \\
\hline SVL & $513 \mathrm{~mm}$ & $198 \mathrm{~mm}$ \\
\hline TL & $125 \mathrm{~mm}$ & $56 \mathrm{~mm}$ \\
\hline TL/Total length & 0.2 & 0.22 \\
\hline HW & $11.9 \mathrm{~mm}$ & $4.7 \mathrm{~mm}$ \\
\hline HL & $16.3 \mathrm{~mm}$ & $8.1 \mathrm{~mm}$ \\
\hline HW/HL & 0.73 & 0.58 \\
\hline
\end{tabular}




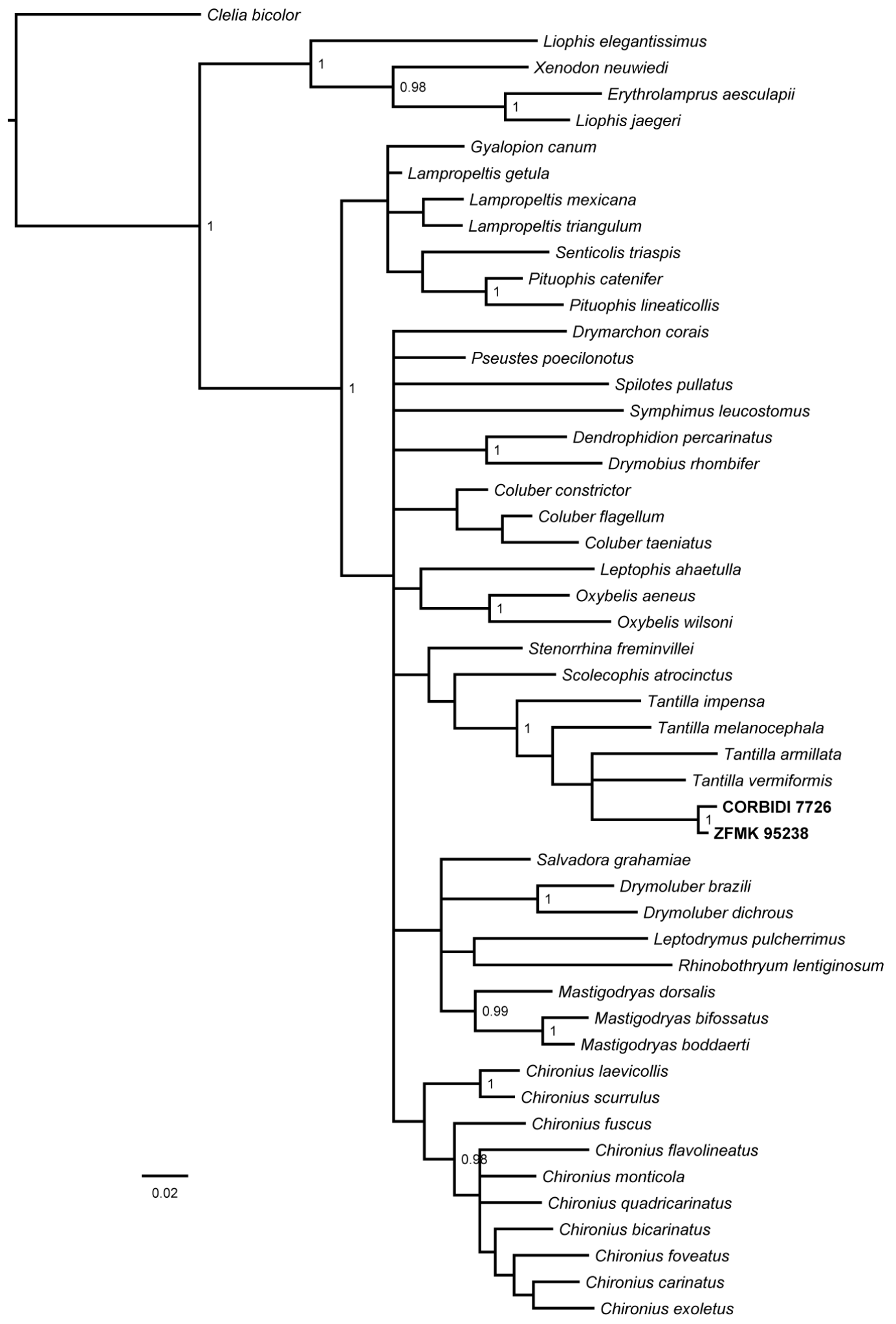

441 Figure 1. Bayesian consensus tree based on 788 bp of mitochondrial DNA (12S and 16S rRNA)

442 of our specimens (CORBIDI 7726 and ZFMK 95238) and 48 further species representing 27

443 genera of American colubrid snakes. Numbers at nodes are the Bayesian posterior probabilities

444 (values $<0.95$ not shown). 
A

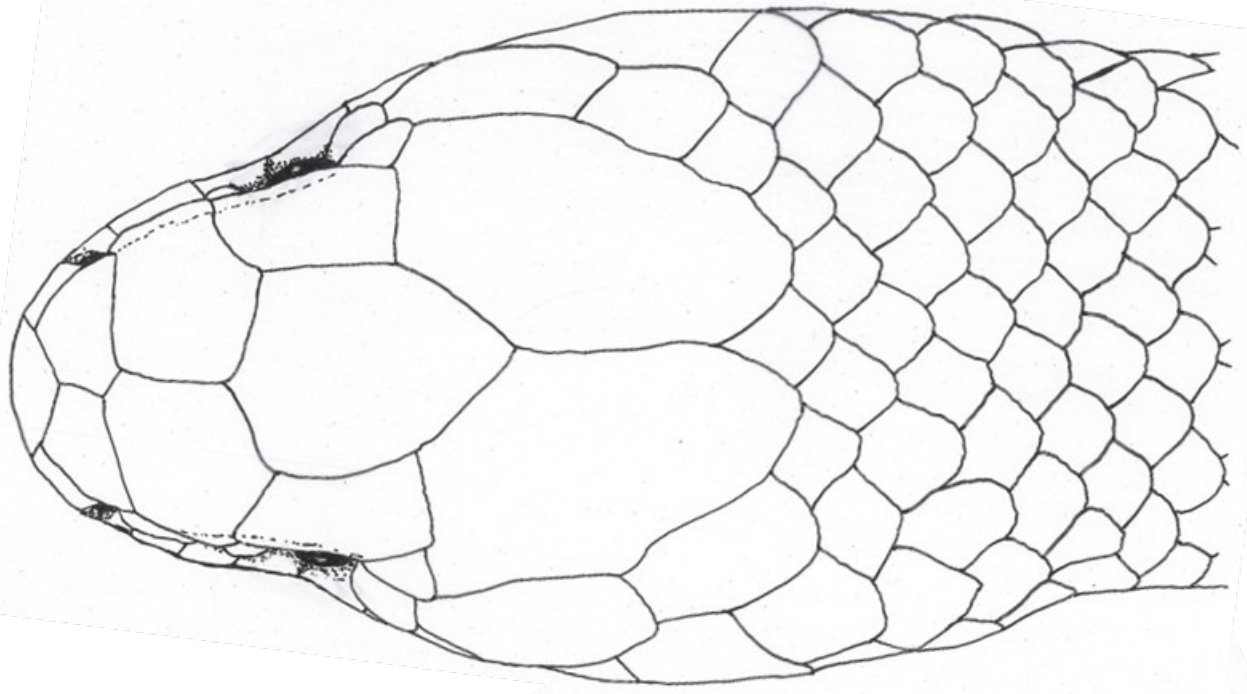

B

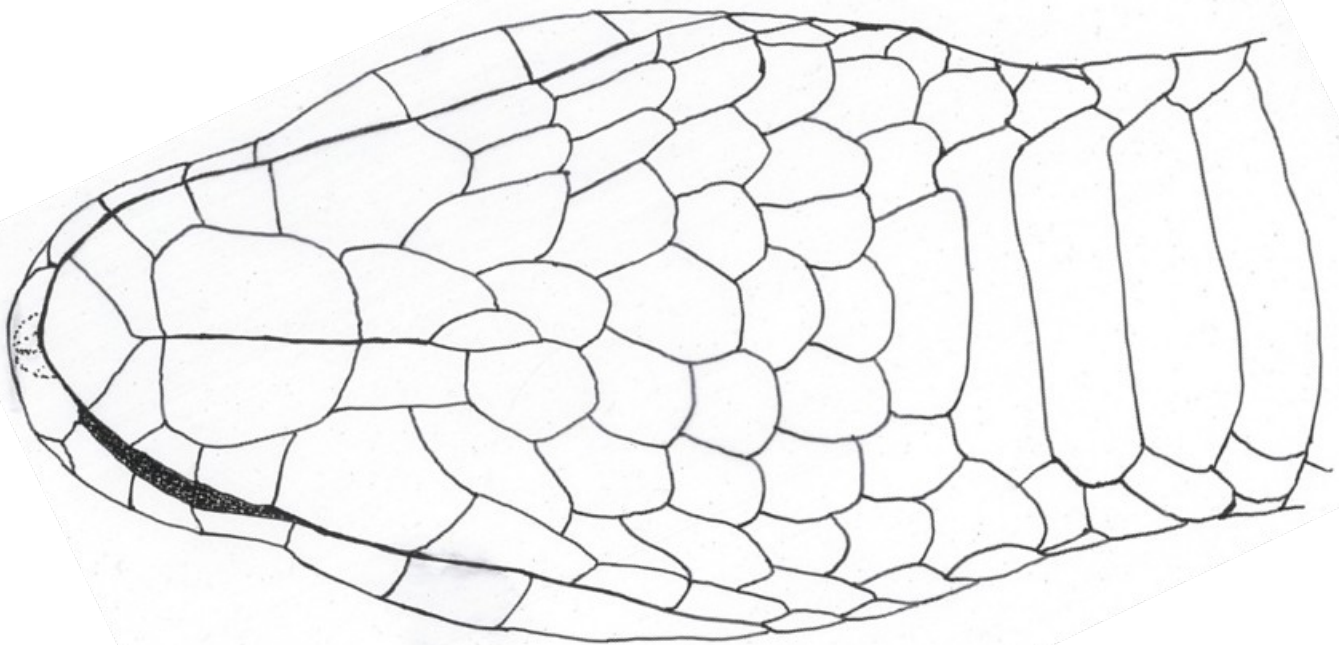

C

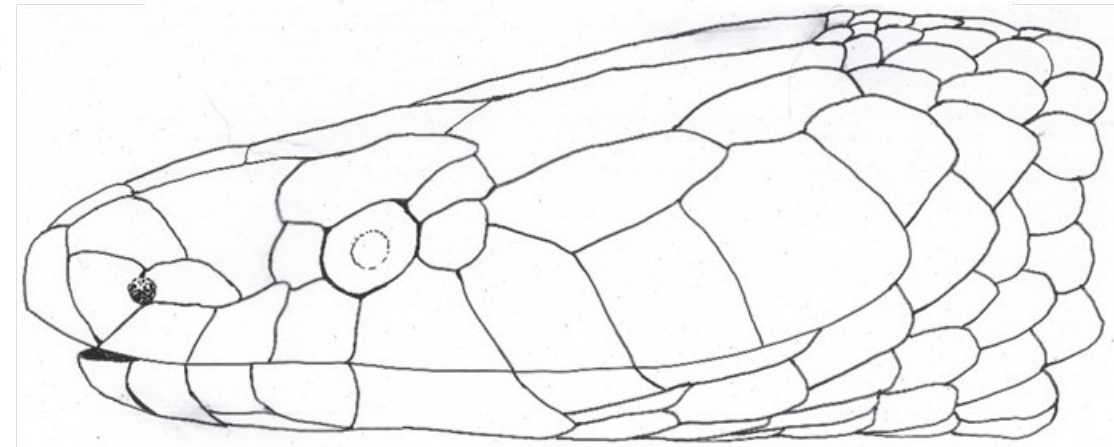

445

446 Figure 2. Dorsal (A), ventral (B) and lateral (C) views of head of female holotype of Tantilla 447 tjiasmantoi sp. nov. from La Libertad, Peru (CORBIDI 7726). 


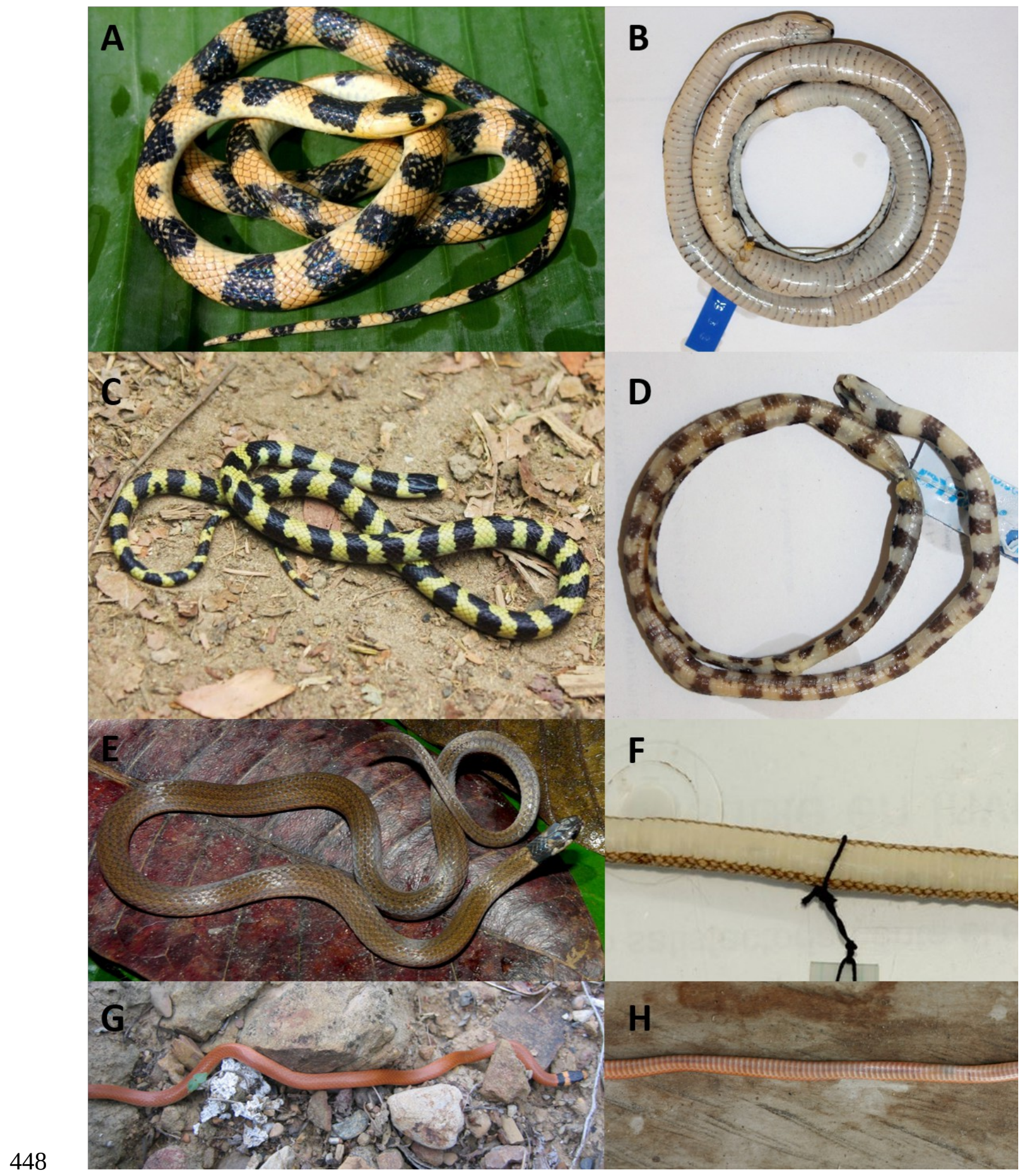

449 Figure 3. Dorsal (left) and ventral (right) views of the species of Tantilla fom Peru: $T$.

450 tjiasmantoi sp. nov. female holotype CORBIDI 7726 (A, B) and male paratype ZFMK 95238 (C,

451 D); T. melanocephala (E, F) from Bahuaja-Sonene, Madre de Díos (photographs by Roy Santa

452 Cruz); T. capistrata (G, H) from near Santa Catalina de Chongoyape, Lambayeque. 


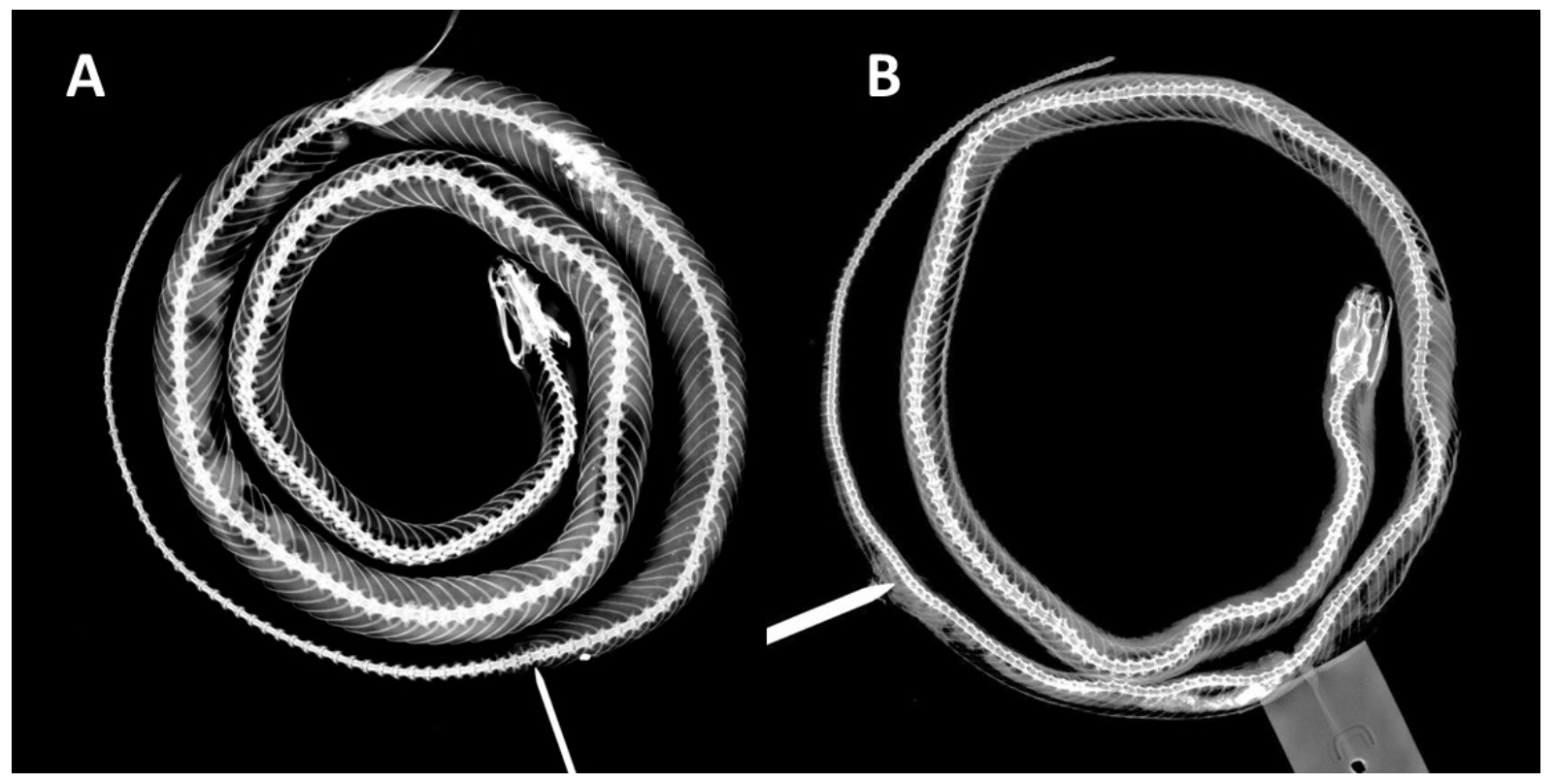

454 Figure 4. X-ray photographies of body of Tantilla tjiasmantoi sp. nov. from La Libertad, Peru

455 (needle marks the cloaca): female holotype CORBIDI 7726 (A) and male paratype ZFMK 95238 456 (B). 


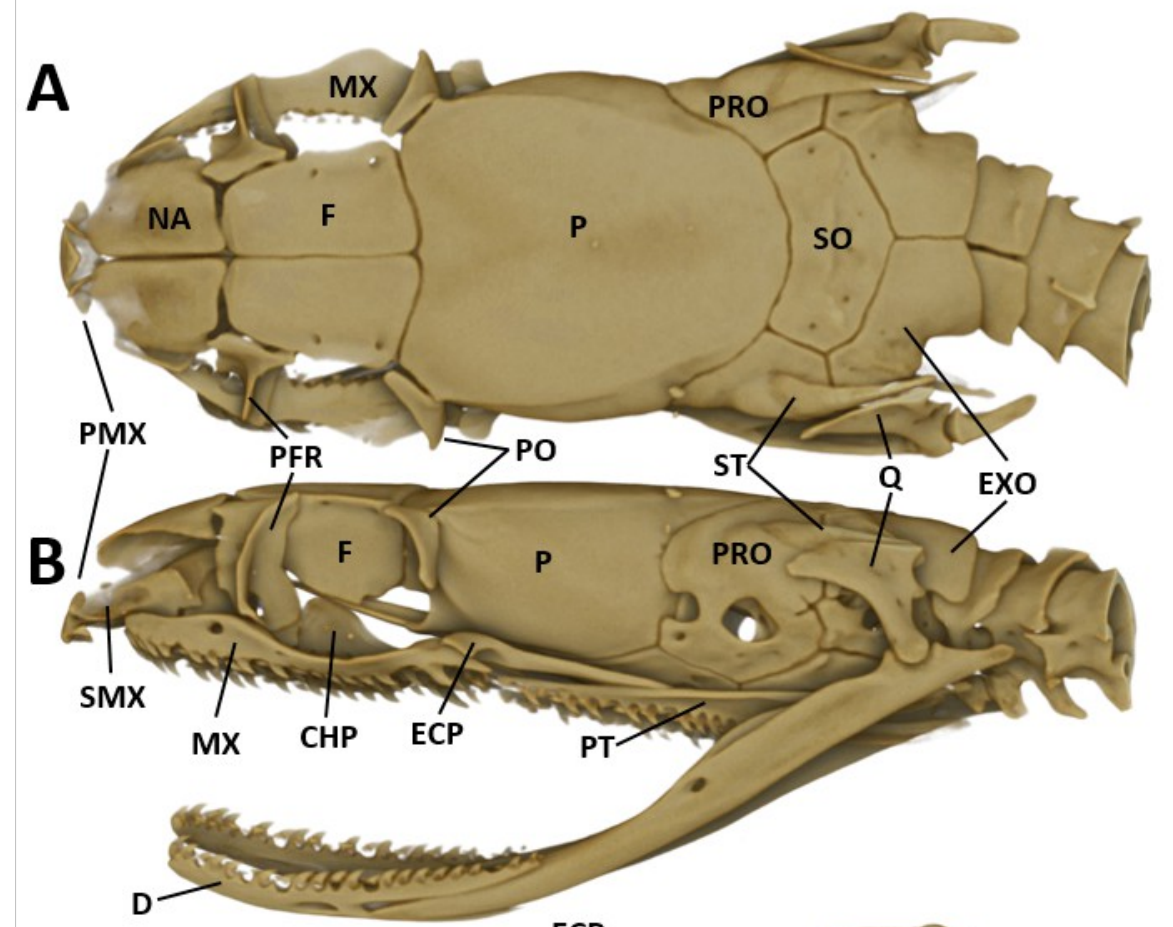

457

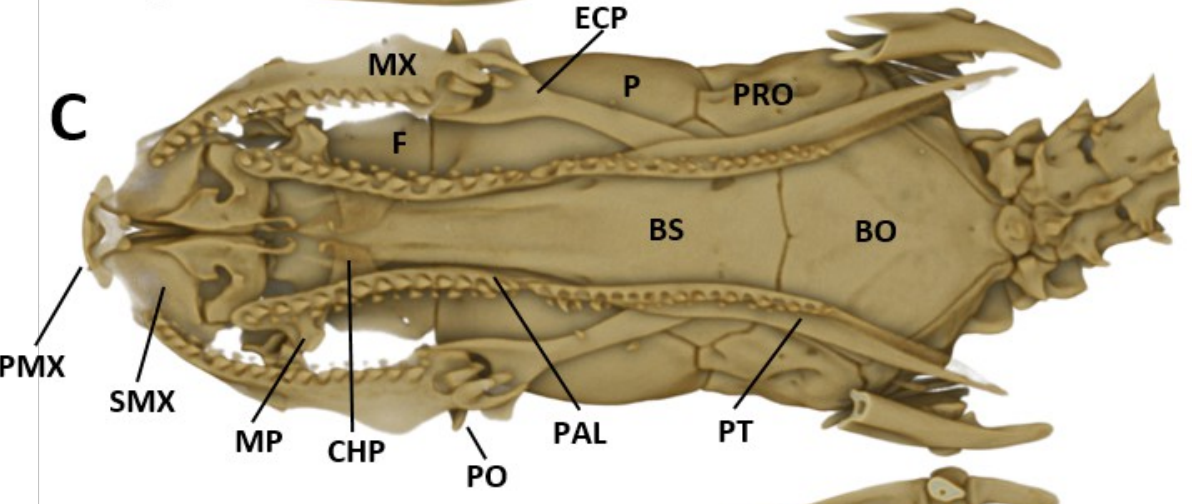

D

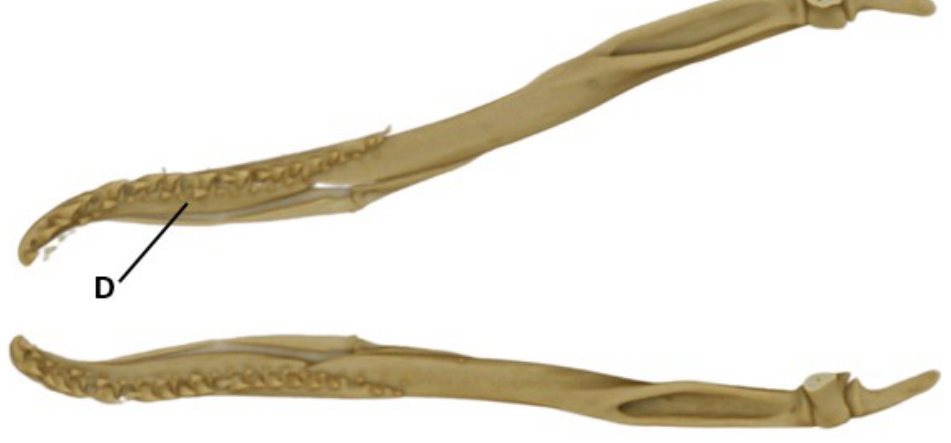

458 Figure 5. Micro-CT images of the male paratype of Tantilla tjiasmantoi sp. nov. from La 459 Libertad: dorsal (A), lateral (B), and ventral views of the skull (C, lower jaw removed), and 460 dorsal view of lower jaw (D). See Materials and Methods section for explanation of the 461 abbreviations of the skull structures. 

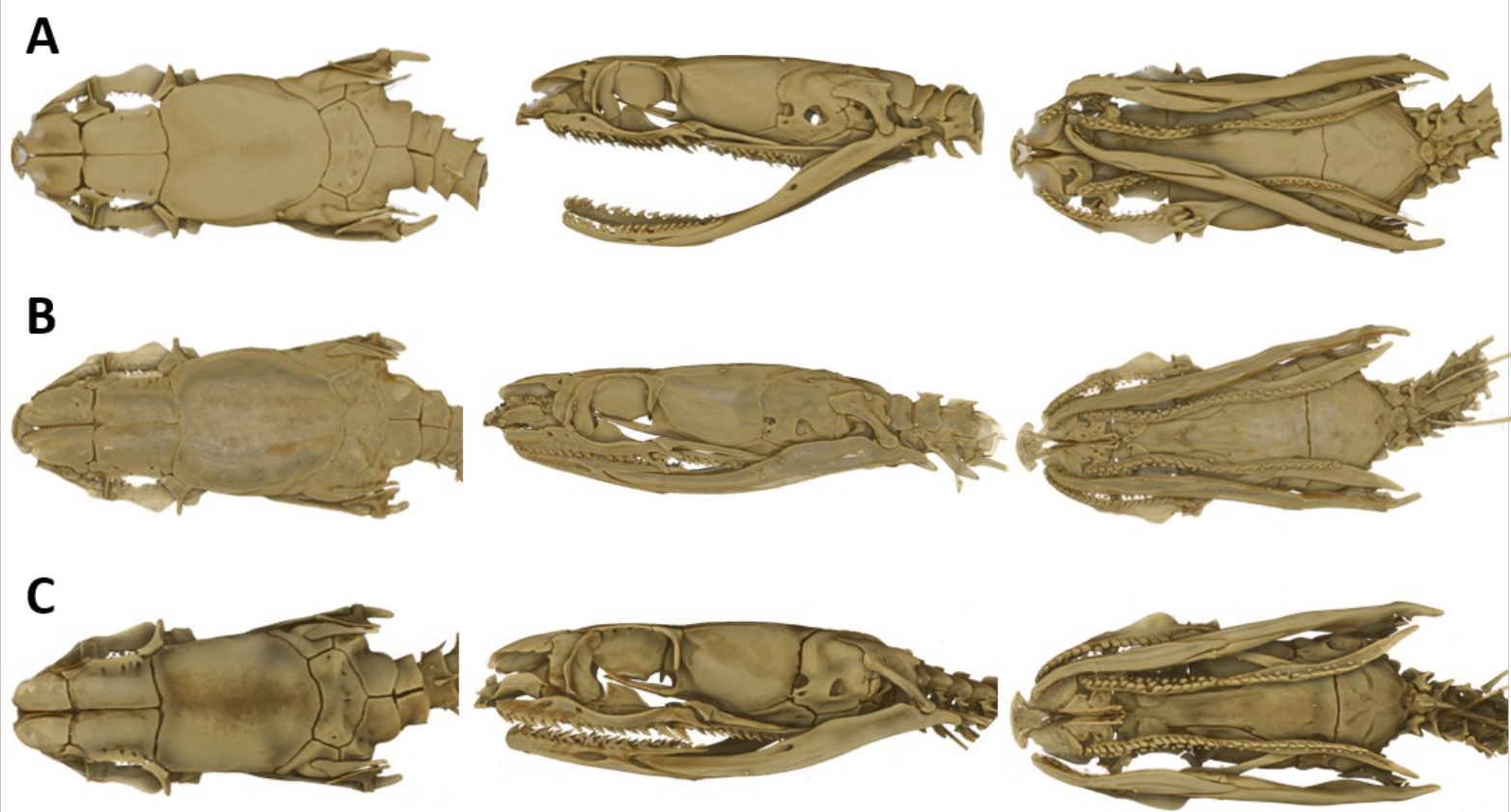

\section{D}

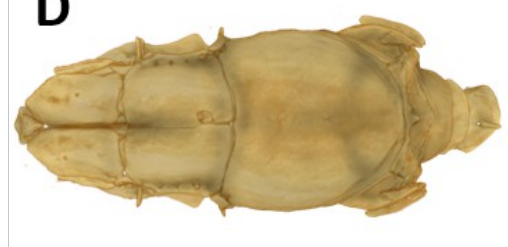

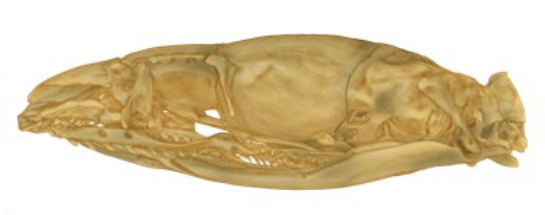

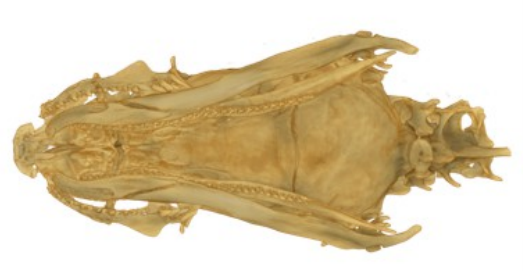

463 Figure 6. Micro-CT images of the dorsal (left), lateral (middle), and ventral (right) views of the 464 skull of foue species of Tantilla: T. tjiasmantoi sp. nov. from Peru (ZFMK 95238,A), T. 465 capistrata from Lambayeque, Peru (ZFMK 85028, B), T. melanocephala from Santa Cruz, 466 Bolivia (ZFMK 75041, C) and T. relicta from Florida, USA (ZFMK 84387, D). 


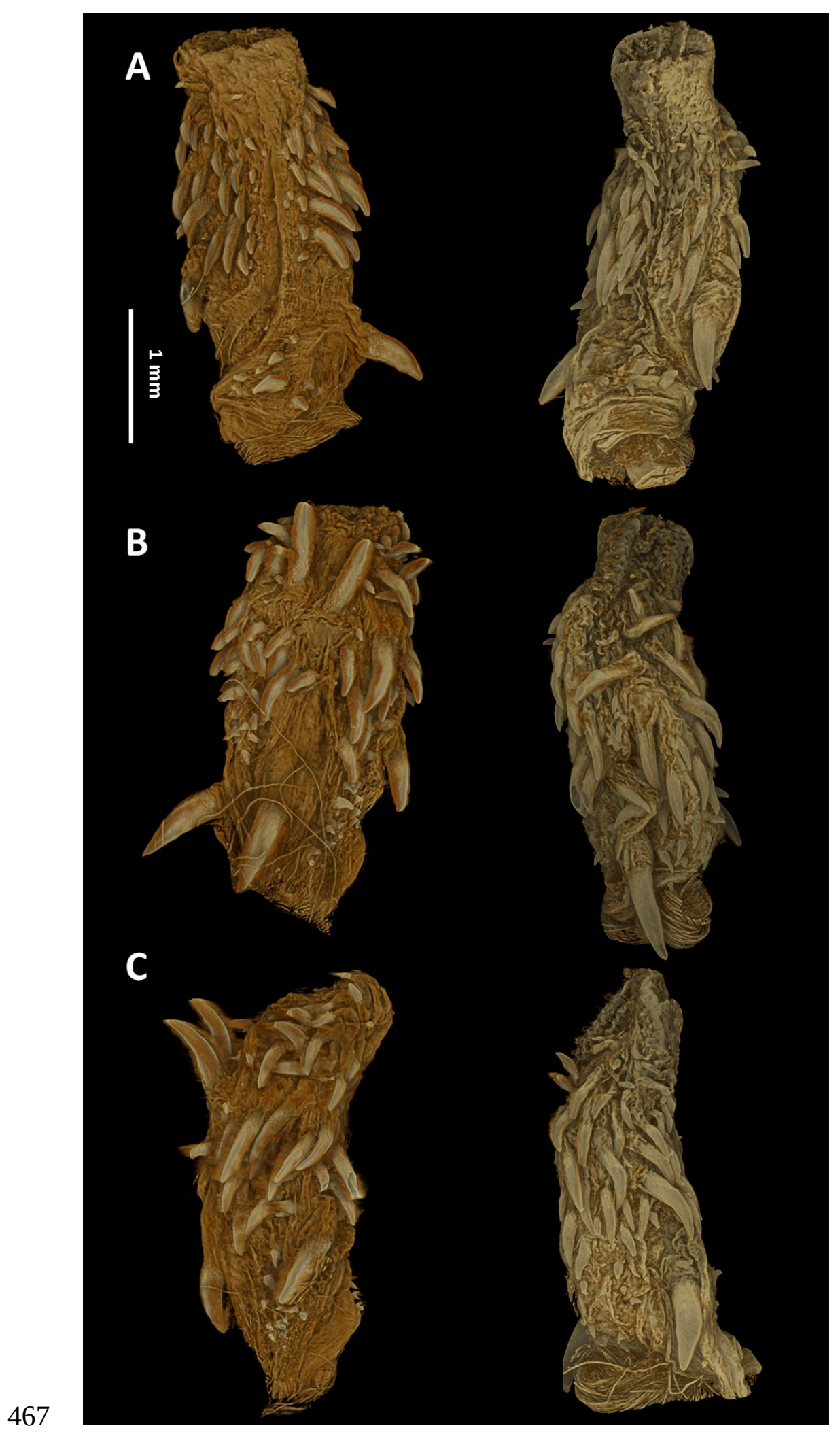

468 Figure 7. Micro-CT images of the hemipenes of the male paratype of Tantilla tjiasmantoi sp. nov.

469 from La Libertad: sulcate (A), asulcate (B), and lateral views (C) of the left (left) and right (right)

470 hemipenis. Left hemipenis was scanned dry, whereas right hemipenis was scanned in alcohol. 

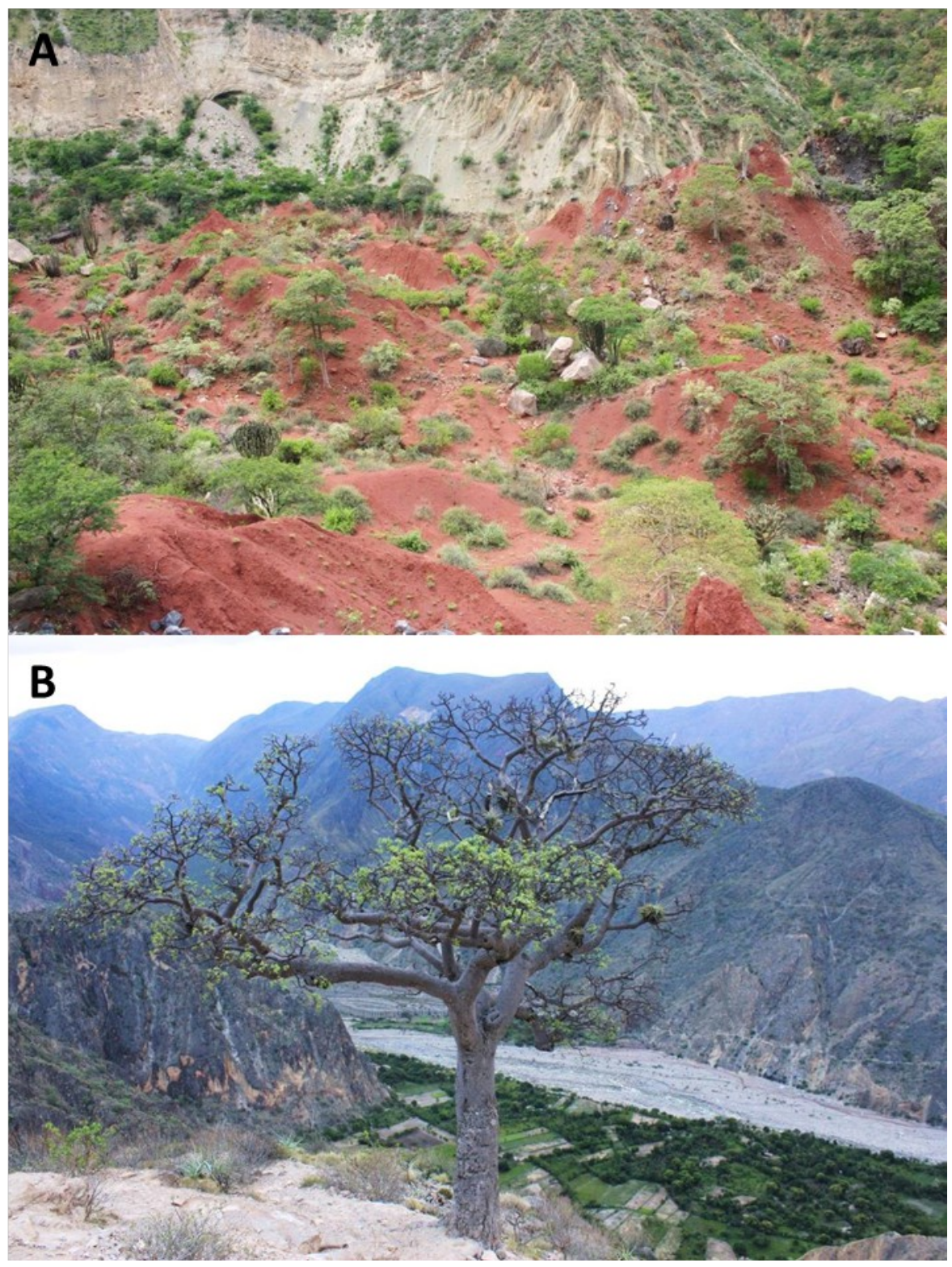

472 Figure 8. Habitat and localities of the holotype of Tantilla tjiasmantoi sp. nov. CORBIDI 7726

473 near Laguna de Pías, La Libertad, Peru (A), and male paratype ZFMK 95238 near Santa Rosa de 474 Marcamachay, La Libertad, Peru (B).

475 


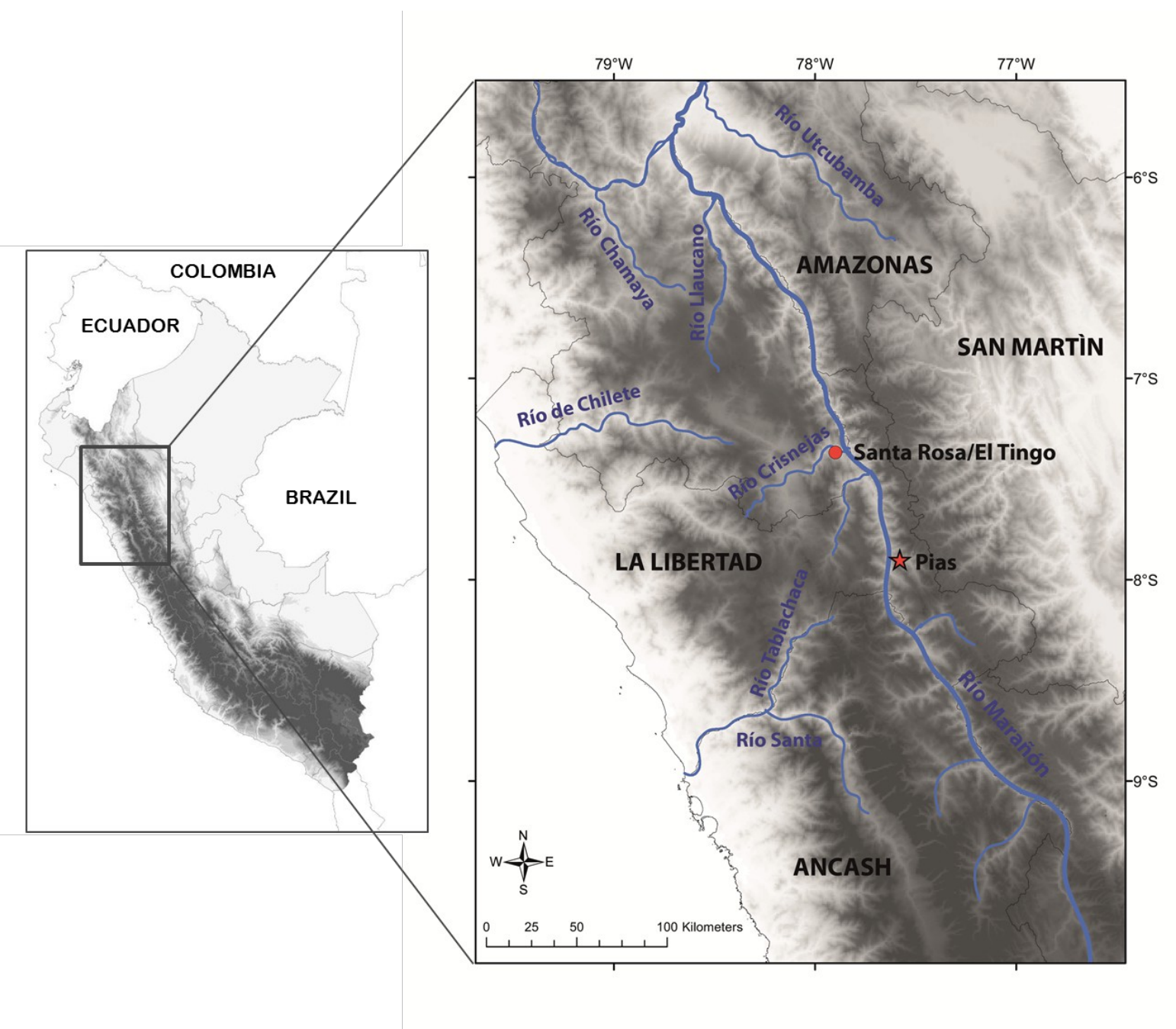

476

477 Figure 9. Map with type locality of Tantilla tjiasmantoi sp. nov. (red star), and locality of male 478 paratype (red dot) in the northern Peruvian Andes. 
480

481

482

483

484

485

486

487

488

489

490

491

492

493

494

495

496

497

498

499

500

501

502

503

504

505

506

507

508

509

510

508

\section{REFERENCES}

Brack A. 1986. Las Ecoregiones del Perú. Boletín de Lima 44: 57-70.

Bridgewater S, Pennington RT, Reynel CA, Daza A, Pennington TD. 2003. A preliminary floristic and phytogeographic analysis of the woody flora of seasonally dry forests in northern Peru. Candollea 58: 129-141.

Bullock RE, Tanner WW. 1966. A comparative osteological study of two species of Colubridae (Pituophis and Thamnophis). Brigham Young University Science Bulletin, Biological Series 8(3): $1-29$.

Burbrink FT, Myers EA. 2015. Both traits and phylogenetic history influence community structure in snakes over steep environmental gradients. Ecography 38: 1-13. DOI:

10.1111/ecog.01148.

Cacciali P, Carreira S, Scott NJ. 2007. Redescription of Phalotris nigrilatus Ferrarezzi, 1993 (Serpentes: Colubridae: Xenodontinae). Herpetologica 63(4): 552-559. DOI: 10.1655/00180831(2007)63[552:ROPNFS]2.0.CO;2.

Campbell JA. 1998. Comments on the identities of certain Tantilla (Squamata: Colubridae) from Guatemala, with descriptions of two new species. Scientific Papers of the Natural History Museum, University of Kansas 7:1-14. DOI: 10.5962/bhl.title.16234.

Campbell JA, Camarillo JL, Ustach PC. 1995. Redescription and rediagnosis of Tantilla shawi (Serpentes: Colubridae) from the Sierra Madre Oriental of Mexico. The Southwestern Naturalist 40(1): 120-132.

Campbell JA, Smith EN. 1998. A new genus and species of colubrid snake from the Sierra de las Minas of Guatemala. Herpetologica 54: 207-220. 
511 Castresana J. 2000. Selection of conserved blocks from multiple alignments for their use in

512 phylogenetic analysis. Molecular Biology and Evolution 17: 540-552. DOI:

513 10.1093/oxfordjournals.molbev.a026334.

514

515 Cei JM. 1993. Reptiles del noroeste, nordeste y este de la Argentina. Torino: Museo Regionale

516 Scienze Naturali Torino, Monografie 14, 949 pp.

517

518 Chambers EA, Hebert PDN. 2016. Assessing DNA barcodes for species identification in North

519 American reptiles and amphibians in natural history collections. PLoS ONE 11(4): e0154363.

520 DOI: 10.1371/journal.pone.0154363.

521

522 Crump ML, Scott NJ. 1994. Visual encounter surveys. In: Heyer WR, Donnelly MA, McDiarmid

523 RW, Hayek LC, Foster MS, eds. Measuring and monitoring biological diversity, standard

524 methods for amphibians. Washington, DC: Smithsonian Institution Press, 84-92.

525

526 Cundall D, Irish FJ. 2008. The snake skull. In: Gans C, Gaunt AS, Adler K, eds. Biology of the

527 Reptilia, volume 20, Morphology H. The skull of Lepidosauria. Ithaca: Society for the Study of

528 Amphibians and Reptiles, 349-692.

529

530 Dowling HG. 1951. A proposed standard system of counting ventrals in snakes. British Journal

531 of Herpetology 1: 97-99.

532

533 DRYFLOR. 2016. Plant diversity patterns in neotropical dry forests and their conservation

534 implications. Science 353 (6306): 1383-1387. DOI: 10.1126/science.aaf5080.

536 Ferrarezzi H. 1993. Nota sobre o genero Phalotris com revisao do grupo nasutus e descricao de

537 tres novas especies (Serpentes, Colubridae, Xenodontinae). Memorias do Instituto Butantan, Sao

538 Paulo 55 (Suppl. 1): 21-38.

539

540 Finer M, Jenkins CN. 2012. Proliferation of hydroelectric dams in the Andean Amazon and

541 implications for Andes-Amazon connectivity. PLoS ONE 7(4): e35126. DOI:

542 10.1371/journal.pone.0035126. 
544 Franco FL, Marques OAV, Puorto G. 1997. Two new species of colubrid snakes of the genus

545 Clelia from Brazil. Journal of Herpetology 31(4): 483-490. DOI: 10.2307/1565599.

546

547 Fritts TH, Smith HM. 1969. A new genus and species of snake from western Ecuador.

548 Transactions of the Kansas Academy of Sciences 72(1): 60-66. DOI: 10.2307/3627049.

550 Hall TA. 1999. BioEdit: a user-friendly biological sequence alignment editor and analysis

551 program for Windows 95/98/NT. Nucleic Acids Symposium Series 41: 95-98.

552

553 Harvey MB, Rivas Fuenmayor G, Rances Caicedo-Portilla J, Rueda-Alm JV. 2008. Systematics

554 of the enigmatic Dipsadine Snake Tropidodipsas perijanensis Alemán (Serpentes: Colubridae)

555 and review of morphological characters of Dipsadini. Herpetological Monographs 22(1): 106-

556 132. DOI: $10.1655 / 08-025.1$.

557

558 IUCN, UNEP-WCMC. 2016. The World Database on Protected Areas (WDPA) [On-line].

559 Available at http://www.protectedplanet.net (accessed 27 June 2016).

560

561 Jansen M, Köhler G. 2008. A new species of Phalotris from the eastern lowlands of Bolivia

562 (Reptilia, Squamata, Colubridae). Senckenbergiana Biologica 88(1): 103-110.

564 Janzen DH. 1988. Tropical dry forests: the most endangered major tropical ecosystem. In: Wilson

565 EO, Peter FM, ed. Biodiversity. Washington, DC: National Academy Press: 130-137.

566

567 Katoh K, Asimenos G, Toh H. 2009. Multiple Alignment of DNA Sequences with MAFFT.

568 Methods in Molecular Biology 537: 39-64. DOI: 10.1007/978-1-59745-251-9_3.

569

570 Koch C, Venegas PJ, Böhme W. 2006. A remarkable discovery: Description of a big-growing

571 new gecko (Squamata: Gekkonidae: Phyllopezus) from northwestern Peru. Salamandra 42(2/3):

572 145-150.

573 
574 Koch C, Venegas PJ, Böhme W. 2015. Three new endemic species of Epictia Gray, 1845

575 (Serpentes: Leptotyphlopidae) from the dry forest of northwestern Peru. Zootaxa 3964(2): 228-

576 244. DOI: 10.11646/zootaxa.3964.2.4.

577

578 Koch C, Venegas PJ, Garcia-Bravo A, Böhme W. 2011. A new bush anole (Iguanidae:

579 Polychrotinae: Polychrus) from the upper Marañón basin, Peru, with a redescription of Polychrus 580 peruvianus (Noble, 1924) and additional information on P. gutturosus Berthold, 1845. Zookeys

581 141: 79-107. DOI: 10.3897/zookeys.141.1678.

582

583 Koch C, Venegas PJ, Rödder D, Flecks M, Böhme W. 2013. Two new endemic species of Ameiva 584 (Squamata: Teiidae) from the dry forest of northwestern Peru and additional information on 585 Ameiva concolor Ruthven, 1924. Zootaxa 3745(2): 263-295. DOI: 10.11646/zootaxa.3745.2.6.

587 Kocher TD, Thomas WK, Meyer A, Edwards SV, Pääbo S, Villablanca FX, Wilson AC. 1989.

588 Dynamics of mitochondrial DNA evolution in animals: amplification and sequencing with 589 conserved primers. Proceedings of the National Academy of Sciences of United States of America 590 86(16): 6196-6200. DOI: 10.1073/pnas.86.16.6196.

591

592 Köhler G. 2003. Reptiles of Central America. Ind Ed. Offenbach: Herpeton-Verlag, 367 pp. 593

Köhler G. 2008. Reptiles of Central America. 2nd Ed. Offenbach: Herpeton-Verlag, 400 pp. 595

596 Kornacker PM. 1999. Checklist and key to the snakes of Venezuela. Rheinbach: PaKo-Verlag, 597 Germany, $270 \mathrm{pp}$.

Lawson R, Slowinski JB, Crother BI, Burbrink FT. 2005. Phylogeny of the Colubroidea

600 (Serpentes): New evidence from mitochondrial and nuclear genes. Molecular Phylogenetics and 601 Evolution 37: 581-601. DOI:10.1016/j.ympev.2005.07.016.

602

603 Lees AC, Peres CA, Fearnside,PM, Schneider M, Zuanon JAS. Hydropower and the future of 604 Amazonian biodiversity. Biodiversity and Conservation 25 (3): 451-466. DOI: 10.1007/s10531605 016-1072-3.

606 
607 Lema T, D’Agostini FM, Cappelari LH. 2005. Nova espécie de Phalotris, redescricåo de $P$.

608 tricolor e osteologia craniana (Serpentes, Elapomorphinae). Iheringia, Série Zoologia 95: 65-78.

609 DOI: 10.1590/s0073-47212005000100010.

610

611 Linares-Palomino R. 2006. Phytogeography and floristics of Seasonally Dry Tropical Forests in

612 Peru. In: Pennington RT, Ratter JA, Lewis GP, eds. Neotropical Savannas and Seasonally Dry

613 Forests: Plant Diversity, Biogeography and Conservation. Boca Raton: CRC Press, 257-279.

614 DOI: 10.1201/9781420004496.ch11.

615

616 Linares-Palomino R, Oliveira-Filho AT, Pennington RT. 2011. Neotropical Seasonally Dry

617 Forests: Diversity, Endemism, and Biogeography of Woody Plants In: Dirzo R, Young HS,

618 Mooney HA, Ceballos G, eds. Seasonally Dry Tropical Forests: Ecology and Conservation.

619 Washington: Island Press, 3-21. DOI 10.5822/978-1-61091-021-7_1.

620

621 Mata-Silva V, Wilson LD. 2016. The taxonomic status of Tantilla marcovani Lema 2004

622 (Squamata: Colubridae). Zootaxa 4092(3): 421-425. DOI: 10.11646/zootaxa.4092.3.7.

623

624 McCranie JR, Castaneda FE. 2004. Notes on the second specimens of Geophis damiani Wilson,

625 McCranie, and Williams and Rhadinaea tolpanorum Holm and Cruz D. (Colubridae).

626 Herpetological Review 35(4): 341.

627

628 McCranie JR, Villa J. 1993. A new genus for the snake Enulius sclateri (Colubridae:

629 Xenodontinae). Amphibia-Reptilia 14(3): 261-267. DOI: 10.1163/156853893x00453.

630

631 McCranie JR, Wilson LD. 1991. Rhadinaea montecristi Mertens. Catalogue of American

632 Amphibians and Reptiles 524: 1-2.

633

634 McCranie JR, Wilson LD. 1991. Rhadinaea kinkelini Boettger. Catalogue of American

635 Amphibians and Reptiles 523: 1-2.

636

637 McCranie JR, Wilson LD. 1992. Rhadinaea godmani. Catalogue of American Amphibians and 638 Reptiles 546: 1-3.

639 
640 Miles L, Newton AC, DeFries RS, Ravilious C, May I, Blyth S, Kapos V, Gordon JE. 2006. A

641 global overview of the conservation status of tropical dry forests. Journal of Biogeography 33:

642 491-505. DOI: 10.1111/j.1365-2699.2005.01424.x.

643 Moura Ribeiro M, Caldeira Costa H, Magalhães Pirani R. 2013. Rediscovery of Phalotris

644 concolor (Serpentes: Dipsadidae: Elapomorphini). Zoologia 30(4): 430-436. DOI:

$64510.1590 / \mathrm{s} 1984-46702013000400009$.

646

647 Murphy PG, Lugo AE. 1986. Ecology of tropical dry forest. Annual Review of Ecology and

648 Systematics 17: 67-88. DOI: 10.1146/annurev.es.17.110186.000435.

649 Myers CW, Cadle JE. 1994. A new genus for South American snakes related to Rhadinaea obtusa

650 Cope (Colubridae) and resurrection of Taeniophallus Cope for the "Rhadinaea" brevirostris

651 group. American Museum Novitates 3102: 1-33.

652

653 Myers CW, McDowell SB. 2014. New taxa and cryptic species of Neotropical snakes

654 (Xenodontinae), with commentary on hemipenes as generic and specific characters. Bulletin of

655 the American Museum of Natural History 385(1): 1-112. DOI: 10.1206/862.1.

656

657 Myers CW. 1973. A new genus for Andean snakes related to Lygophis boursieri and a new

658 species (Colubridae). American Museum Novitates 2522: 1-37.

659

660 Myers CW. 2011. A new genus and new tribe for Enicognathus melanauchen Jan, 1863, a

661 neglected South American snake (Colubridae: Xenodontinae), with taxonomic notes on some

662 Dipsadinae. American Museum Novitates 3715: 1-33. DOI: 10.1206/3715.2.

663

664 Palumbi SR, Martin A, Romano S, McMillan WO, Stice L, Grabowski G. 1991. The Simple

665 Fool's Guide to PCR, Version 2. Honolulu: University of Hawaii Zoology Department, 94 pp.

666

667 Passos P, Ramos L, Pereira DN. 2012. Distribution, natural history, and morphology of the rare

668 snake, Caaeteboia amarali (Serpentes: Dipsadidae). Salamandra 48(1): 51-58.

669

670 Pennington RT, Lewis GP, Ratter JA. 2006. An Overview of the Plant Diversity, Biogeography

671 and Conservation of Neotropical Savannas and Seasonally Dry Forests. In: Pennington RT, Ratter 
672 JA, Lewis GP, eds. Neotropical Savannas and Seasonally Dry Forests: Plant Diversity,

673 Biogeography and Conservation. Boca Raton: CRC Press, 1-29. DOI:

674 10.1201/9781420004496.ch1.

675

676 Peracca MG. 1904. Nouvelles espèces d'Ophidiens d'Asie et d'Amerique, faisant partie de la 677 collection du Museum d'histoire naturelle de Genève. Revue Suisse de Zoologie 12: 663-668.

678 DOI: 10.5962/bhl.part.10151.

679

680 Pérez-Santos C, Moreno AG. 1988. Ofidios de Colombia. Torino: Museo Regionale di Scienze 681 Naturali, Monographie VI, 517 pp.

682

683 Peters JA, Donoso-Barros R, Orejas-Miranda B. 1970. Catalogue of the Neotropical Squamata:

684 Part I Snakes. Part II Lizards and Amphisbaenians. United States National Museum Bulletin 297:

$6851-347$.

686

687 Peters JA. 1960. The snakes of the subfamily Dipsadinae. Miscellaneous Papers of the Museum 688 of Zoology, University of Michigan 114: 1-224.

689

690 Posada D, Crandall KA. 1998. MODELTEST: testing the model of DNA substitution.

691 Bioinformatics 14: 817-818. DOI: 10.1093/bioinformatics/14.9.817.

692

693 Puorto G, Ferrarezzi H. 1993. Uma nova especie de Phalotris Cope, 1862, com comentarios

694 sobre o grupo bilineatus (Serpentes: Colubridae: Xenodontinae). Memorias do Instituto

695 Butantan, Sao Paulo 55 (Suppl. 1): 39-46.

696

697 Q\&V Ingenieros SAC. 2007. Elaboración de resúmenes ejecutivos y fichas de estudio de las

698 centrales hidroeléctricas con potencial para exportación a Brasil. Ministerio de Energía y Minas,

699 Dirección General de Electricidad, 79 pp.

700

701 Rambaut A, Suchard MA, Xie D, Drummond AJ. 2014. Tracer v1.6, Available at 702 http://beast.bio.ed.ac.uk/Tracer (accessed on 08 August 2016). 
704 Ronquist F, Teslenko M, van der Mark P, Ayres DL, Darling A, Höhna S, Larget B, Liu L, 705 Suchard MA, Huelsenbeck JP. 2012. MrBayes 3.2: efficient Bayesian phylogenetic inference and 706 model choice across a large model space. Systematic Biology 61: 539-542. DOI: 707 10.1093/sysbio/sys029.

708

709 Särkinen TE, Marcelo-Peña JL, Daza Yomona A, Simon MF, Pennington RT, Hughes CE. 2011.

710 Underestimated endemic species diversity in the dry inter-Andean valley of the Río Marañón, 711 northern Peru: An example from Mimosa (Leguminosae, Mimosoideae). Taxon 60(1): 139-150. 712

713 Savage JM. 2002. The amphibians and reptiles of Costa Rica: A herpetofauna between two 714 continents, between two seas. Chicago: University of Chicago Press, 934 pp.

716 Savage JM, Crother BI. 1989. The status of Pliocercus and Urotheca (Serpentes: Colubridae), 717 with a review of included species of coral snake mimics. Zoological Journal of the Linnean 718 Society 95: 335-362. DOI: 10.1111/j.1096-3642.1989.tb02315.x.

720 Savage JM, Donnelly MA. 1988. Variation and systematics in the colubrid snakes of the genus 721 Hydromorphus. Amphibia-Reptilia 9: 289-300. DOI: 10.1163/156853888x00378.

Sawaya RJ, Sazima I. 2003. A new species of Tantilla (Serpentes: Colubridae) from southeastern Brazil. Herpetologica 59(1): 119-126. DOI: 10.1655/0018-0831(2003)059[0119:ansots]2.0.co;2.

Schrey AW, Evans RK, Netherland M, Ashton KG,Mushinsky HR, Mccoy ED. 2015. Ridge in Central Florida. Journal of Herpetology 49(3): 415-419. DOI: 10.1670/13-190.

731 Schulte II JA, Cartwright EM. 2009. Phylogenetic relationships among iguanian lizards using 732 alternative partitioning methods and TSHZ1: a new phylogenetic marker for reptiles. Molecular 733 Phylogenetics and Evolution 50: 391-396. DOI: 10.1016/j.ympev.2008.10.018. 
735 Scott NJ, Giraudo AR, Scrocchi G, Aquino AL, Cacciali P, Motte M. 2006. The genera Boiruna

736 and Clelia (Serpentes: Pseudoboini) in Paraguay and Argentina. Papéis Avulsos de Zoologia (São

737 Paulo) 46(9): 77-105. DOI: 10.1590/S0031-10492006000900001.

738

739 Slevin JR. 1942. Notes on a collection of reptiles from Boquete, Panama, with the description of

740 a new species of Hydromorphus. Proceedings of the California Academy Sciences 23: 463-480.

741

742 Smith EN, Campbell JA. 1994. A new species of Rhadinea (Colubridae) from the Caribbean

743 Versant of Guatemala. Occasional Papers of the Museum of Natural History, University of

744 Kansas 167: 1-9.

745

746 Smith HM, Taylor EH. 1945. An annotated checklist and key to the snakes of Mexico. United

747 States National Museum Bulletin 187: iv + 1-239.

748

749 Solorzano A. 2004. Serpientes de Costa Rica - Snakes of Costa Rica. Costa Rica: Editorial INBio, $750,792 \mathrm{pp}$.

751

752 Stafford PJ. 2004. A new species of Tantilla (Serpentes; Colubridae) of the taeniata group from

753 Southern Belize. Journal of Herpetology 38(1): 43-52. DOI: 10.1670/208-02a.

754

755

Stamatakis A, Hoover P, Rougemont J. 2008. A Rapid Bootstrap Algorithm for the RAxML Web-

Servers. Systematic Biology 75: 758-771. DOI: 10.1080/10635150802429642

757

758 Starace F. 1998. Guide des Serpents et Amphisbènes de Guyane. Guadeloupe, Guyane: IBIS

759 Rouge Editions, 450 pp.

760

761 Stattersfield AJ, Crosby MJ, Long AJ, Wege D. 1998. Endemic birds areas of the world.

762 Priorities for biodiversity conservation. Cambridge, UK: BirdLife International, 815 pp.

763

764 Stuart LC, Bailey JR. 1941. Three new species of the genus Rhadinaea from Guatemala.

765 Occasional Papers of the Museum of Zoology, University of Michigan 442: 1-11. 
767 Stuart LC. 1949. A new Trimetopon (Ophidia) from Guatemala. Proceedings of the Biological

768 Society of Washington 62: 165-168.

769

770 Stuart LC. 1954. Descriptions of some new amphibians and reptiles from Guatemala.

771 Proceedings of the Biological Society of Washington 67: 159-178.

772

773 Townsend JH, Wilson LD, Medina-Flores M, Herrera LA. 2013. A new species of centipede

774 snake in the Tantilla taeniata group (Squamata: Colubridae) from premontane rainforest in

775 Refugio de Vida Silvestre Texíguat, Honduras. Journal of Herpetology 47: 191-200.

776 http://dx.doi.org/10.1670/11-172.

777

778 Van Denburgh J. 1912. Expedition of the California Academy of Sciences to the Galapagos

779 Islands, 1905-1906. IV. The snakes of the Galapagos Islands. Proceedings of the California.

780 Acadademy of. Sciences (Ser. 4) 1(4): 323-374.

781

782 Venegas PJ. 2005. Herpetofauna del bosque seco Ecuatorial de Peru: taxonomía, ecología y

783 biogeografía. Zonas Áridas 9: 9-26.

784

785 Venegas PJ, Townsend JH, Koch C, Böhme W. 2008. Two new sympatric species of leaf-toed

786 geckos (Gekkonidae: Phyllodactylus) from the Balsas region of the upper Marañón Valley, Peru.

787 Journal of Herpetology 42(2): 386-396. DOI: 10.1670/07-1341.1.

788

789 Vidal N, Kindl SG, Wong A, Hedges SB. 2000. Phylogenetic relationships of Xenodontine snakes

790 inferred from 12S and 16S ribosomal RNA sequences. Molecular Phylogenetics and Evolution

791 14(3): 389-402. DOI: 10.1006/mpev.1999.0717.

792

793 Villa JD. 1971. Crisantophis, a new genus for Conophis nevermanni Dunn. Journal of

794 Herpetology 5: 173-77. DOI: 10.2307/1562739.

795

796 Villa JD. 1990. Hydromorphus Peters. Central American watersnakes. Catalogue of American

797 Amphibians and Reptiles 472: 1-2.

798 
799 Werneck FP, Costa GC, Colli GR, Prado DE, Sites Jr JW. 2011. Revisiting the historical

800 distribution of Seasonally Dry Tropical Forests: new insights based on palaeodistribution

801 modelling and palynological evidencegeb. Global Ecology and Biogeography 20: 272-288. DOI:

802 10.1111/j.1466-8238.2010.00596.x.

803 Werner F. 1924. Neue oder wenig bekannte Schlangen aus dem Naturhistorischen Staatsmuseum

804 in Wien. 1. Teil. Sitzungsberichte der Akademie der Wissenschaften in Wien, Abt. l, 133: 29-56.

805

806 Wilson LD. 1976. Variation in the colubrid snake Tantilla semicincta (Dumeríl, Bibron, and

807 Dumeríl), with comments on pattern dimorphism. Bulletin of the Southern California Academy of

808 Sciences 75: 42-48.

809

810 Wilson LD. 1987. A resume of the Colubrid snakes of the genus Tantilla of South America.

811 Milwaukee Public Museum Contributions in Biology and Geology 68: 1-35.

812

813 Wilson LD. 1999. Checklist and key to the species of the genus Tantilla (Serpentes: Colubridae),

814 with some distributional commentary. Smithsonian Herpetological Information Services 122: 1-

815 34. DOI: $10.5479 /$ si.23317515.122.1.

816

817 Wilson LD, Mata-Silva V. 2014. Snakes of the genus Tantilla (Squamata: Colubridae) in Mexico:

818 taxonomy, distribution, and conservation. Mesoamerican Herpetology 1(1): 5-95.

819

820 Wilson LD, Mata-Silva V. 2015. A checklist and key to the snakes of the Tantilla clade

821 (Squamata: Colubridae), with comments on distribution and conservation. Mesoamerican

822 Herpetology 2(4): 418-498.

823

824 Wilson LD, Mena CE. 1980. Systematics of the melanocephala group of the colubrid snake

825 genus Tantilla. San Diego Society of Natural History Memoirs 11: 5-58.

826

827 Zaher H. 1996. A new genus and species of pseudoboine snake, with a revision of the genus

828 Clelia (Serpentes, Xenodontinae). Bolletino dei Musei Regionale Sciencia naturali di Torino 14:

$829289-337$.

830 
831 Zaher H. 1999. Hemipenial morphology of the South American xenodontine snakes, with a

832 proposal for a monophyletic Xenodontinae and a reappraisal of colubroid hemipenes. Bulletin of

833 the American Museum of Natural History 240:1-168.

834

835 Zaher H, Grazziotin FG, Cadle JE, Murphy RW, Moura-Leite JC. 2009. Molecular phylogeny of

836 advanced snakes (Serpentes, Caenophidia) with an emphasis on South American Xenodontines: a

837 revised classification and descriptions of new taxa. Papéis Avulsos de Zoologia (São Paulo)

838 49(11): 115-153. DOI: 10.1590/S0031-10492009001100001.

839

840 Zaher H, Prudente AL. 2003. Hemipenes of Siphlophis (Serpentes, Xenodontinae) and techniques

841 of hemipenial preparation in snakes: A response to Dowling. Herpetological Review 34: 302-307. 
842 APPENDIX. Additional specimens examined.

843

844 Tantilla capistrata: PERU: Lambayeque: Chaparrí, 446 m a.s.1. (ZFMK 85028).

845 Tantilla melanocephala: BOLIVIA: Santa Cruz: Florida, Pampagrande 446 m a.s.l. (ZFMK 846 75041).

847 Tantilla relicta: USA: Florida: Bushnell (ZFMK 84387). 